\title{
Measurement Report: Optical properties and sources of water-soluble brown carbon in Tianjin, North China: insights from organic molecular compositions
}

Junjun Deng ${ }^{1}$, Hao Ma ${ }^{1}$, Xinfeng Wang ${ }^{2}$, Shujun Zhong $^{1}$, Zhimin Zhang ${ }^{1}$, Jialei Zhu ${ }^{1}$, Yanbing Fan ${ }^{1}$,

5 Wei Hu${ }^{1}$, Libin $\mathrm{Wu}^{1}$, Xiaodong Li ${ }^{1}$, Lujie Ren ${ }^{1}$, Chandra Mouli Pavuluri ${ }^{1}$, Xiaole Pan ${ }^{3}$, Yele Sun ${ }^{3}$, Zifa Wang $^{3}$, Kimitaka Kawamura ${ }^{4}$, and Pingqing $\mathrm{Fu}^{1}$

${ }^{1}$ Institute of Surface-Earth System Science, School of Earth System Science, Tianjin University, Tianjin 300072, China

${ }^{2}$ Environment Research Institute, Shandong University, Jinan 250100, China

${ }^{3}$ State Key Laboratory of Atmospheric Boundary Layer Physics and Atmospheric Chemistry, Institute of Atmospheric

10 Physics, Chinese Academy of Sciences, Beijing 100029, China

${ }^{4}$ Chubu Institute for Advanced Studies, Chubu University, Kasugai 487-8501, Japan

Correspondence to: Pingqing Fu (fupingqing@tju.edu.cn)

Abstract. Brown carbon $(\mathrm{BrC})$ aerosols exert vital impacts on climate change and atmospheric photochemistry due to their light absorption in the wavelength range from near-ultraviolet (UV) to visible light. However, the optical properties and

15 formation mechanisms of ambient $\mathrm{BrC}$ remain poorly understood, limiting the estimation of their radiative forcing. In the present study, fine aerosols $\left(\mathrm{PM}_{2.5}\right)$ were collected during 2016-2017 on a day/night basis over urban Tianjin, a megacity in North China, to obtain seasonal and diurnal patterns of atmospheric water-soluble BrC. There were obvious seasonal but no evident diurnal variations in light absorption properties of $\mathrm{BrC}$. In winter, $\mathrm{BrC}$ showed much stronger light absorbing ability since mass absorption efficiency at $365 \mathrm{~nm}$ (MAE 365$)\left(1.54 \pm 0.33 \mathrm{~m}^{2} \mathrm{~g}^{-1}\right)$, which was 1.8 times larger than that $(0.84 \pm 0.22$ $\mathrm{m}^{2} \mathrm{~g}^{-1}$ ) in summer. Direct radiative effects by $\mathrm{BrC}$ absorption relative to black carbon in the UV range were $54.3 \pm 16.9 \%$ and $44.6 \pm 13.9 \%$, respectively. In addition, five fluorescent components in $\mathrm{BrC}$, including three humic-like fluorophores and two protein-like fluorophores were identified with excitation-emission matrix fluorescence spectrometry and parallel factor (PARAFAC) analysis. The lowly-oxygenated components contributed more to winter and nighttime samples, while moreoxygenated components increased in summer and daytime samples. The higher humification index (HIX) together with lower biological index (BIX) and fluorescence index (FI) suggest that the chemical compositions of $\mathrm{BrC}$ were associated with a high aromaticity degree in summer and daytime due to photobleaching. Fluorescent properties indicate that wintertime $\mathrm{BrC}$ were predominantly affected by primary emissions and fresh secondary organic aerosol (SOA), while summer ones were more influenced by aging processes. Results of source apportionments using organic molecular compositions of the same set of aerosols reveal that fossil fuel combustion and aging processes, primary bioaerosol emission, biomass burning, and biogenic and anthropogenic SOA formation were the main sources of $\mathrm{BrC}$. Biomass burning contributed much larger to $\mathrm{BrC}$ in winter and at nighttime, while biogenic SOA contributed more in summer and at daytime. Especially, our study highlights that primary bioaerosol emission is an important source of $\mathrm{BrC}$ in urban Tianjin in summer. 


\section{Introduction}

Brown carbon $(\mathrm{BrC})$ is light absorbing organic carbon $(\mathrm{OC})$ in the atmosphere, which can absorb radiation in the range from near-ultraviolet (UV) to visible and show strong wavelength dependence (Andreae and Gelencsér, 2006; Bahadur et al., 2012). Although its light absorbing ability is generally weaker than that of black carbon (BC), BrC exerts considerable impacts on atmospheric radiative balance and global climate due to their large abundance and strong light absorption in the near-UV spectrum (Feng et al., 2013; Jo et al., 2016; Zhang et al., 2017; Zhang et al., 2020a). In addition, BrC can efficiently affect the atmospheric photochemistry processes, formation of secondary organic aerosol (SOA) and thus regional air quality by influencing the photolysis rates of atmospheric radicals (Laskin et al., 2015; Moise et al., 2015; Mok et al., 2016; Baylon et al., 2018). Since the last decade, plenty of studies on $\mathrm{BrC}$ aerosols have been performed to explore their optical properties and estimate their environmental and climatic effects (Hecobian et al., 2010; Kirillova et al., 2016; Liu et al., 2016; Huang et al., 2018; Shamjad et al., 2018; Li et al., 2020c; Choudhary et al., 2021).

However, it is quite a challenge to understand the extremely complex chemical composition, sources, and formation and evolution mechanisms of BrC (Laskin et al., 2015; Yan et al., 2018; Wu et al., 2021). On the one hand, atmospheric BrC is derived from incomplete combustion of carbonaceous materials, such as fossil fuel, biomass and biofuel (Chakrabarty et al., 2010; Lack et al., 2012; Lin et al., 2016, 2017; Sun et al., 2017; Lei et al., 2018; Hettiyadura et al., 2021). One the other hand, $\mathrm{BrC}$ can be formed through aqueous-phase or heterogeneous reactions from both biogenic and anthropogenic precursors (Lin et al., 2015; Li et al., 2020a; He et al., 2021). Furthermore, optical properties and chemical compositions of BrC aerosols will undergo significant changes when they are experiencing atmospheric physical and chemical processes such as photochemical aging and hygroscopic growth (Lee et al., 2014; Forrister et al., 2015; Sumlin et al., 2017; Wong et al., 2017; Dasari et al., 2019; Kasthuriarachchi et al., 2020; Palm et al., 2020; Ni et al., 2021). Therefore, despite the progresses reported in recent years, it is needed to further characterize the sources and formation mechanisms of atmospheric BrC, particularly from the perspectives of chromophore and molecular composition (Laskin et al., 2015; Yan et al., 2018).

55 To identify the chromophores in $\mathrm{BrC}$ will be benefit for probing the sources, dynamic optical properties, and aging processes of atmospheric BrC (Laskin et al., 2015; Yan et al., 2020). However, to our best knowledge, until now it is still challengeable to conduct a comprehensive analysis of the chromophores of atmospheric $\mathrm{BrC}$. One great difficulty is to distinguish the absorbing chromophores from a majority of nonchromophoric components. Three-dimensional excitation-emission matrix (EEM) fluorescence spectroscopy is a powerful tool for revealing the chemical compositions, sources, and chemical reactions of complex chromophores in different environments since each chromophore has its own specific excitation-emission peak in the EEM maps (Coble, 1996, 2007; Murphy et al., 2013). In recent years, the fluorescence technique has been used to investigate the characteristics and potential sources of chromophores in aerosols (Mladenov et al., 2011; Fu et al., 2015; Chen et al., 2016, 2020; Qin et al., 2018; Wang et al., 2020; Tang et al., 2020). With the fluorescence technique, some categories of chromophores such as humic-like chromophores and protein-like chromophores can be identified in atmospheric aerosols. 
al., 2021).

The North China Plain (NCP), with a regional population contribution of approximately $25 \%$, is the second largest plain in China. The NCP is also one of the most developed city clusters in China and contains several megacities such as Beijing, Tianjin, and Shijiazhuang. Due to the rapid economic development and intensive anthropogenic activities, the NCP has been suffering severe regional air pollution in the recent years, which has attracted a world-wide concern (Zhao et al., 2013; Guo et al., 2014; Huang et al., 2017; Gao et al., 2018; Ge et al., 2018; Li et al., 2021; Zhang et al., 2021). Despite numerous studies on chemical compositions, source apportionment and formation mechanisms of atmospheric aerosols, current understanding of the optical properties and sources of $\mathrm{BrC}$ aerosols over the NCP are still inadequate. Nevertheless, the limited researches focusing on BrC aerosols are mostly conducted in Beijing (Cheng et al., 2011; Du et al., 2014; Yan et al., 2015, 2020; Li et

75 al., 2020e), while the BrC-related studies in other cities in this hot-spot region are quite scarce and therefore deserve more attention. Located adjacent to Beijing and the Bohai Sea, Tianjin is the largest industrial city and second largest megacity in North China. Previous studies have found that Tianjin experienced serious aerosol pollution with large contribution from anthropogenic activities including coal combustion, industrial and vehicle emissions (Huang et al., 2017; Gao et al., 2018). Abundances and molecular compositions of organic aerosols were investigated and the contributions of primary emission

80 sources and secondary formation to organic aerosols were also evaluated (Fan et al., 2020b). However, optical properties and formation mechanisms of $\mathrm{BrC}$ in Tianjin are still unclear.

In the present study, field measurements of water-soluble $\mathrm{BrC}$ in ambient fine aerosols were performed in urban Tianjin. Seasonal and diurnal variations in optical properties of $\mathrm{BrC}$ were investigated, and direct radiative effects by $\mathrm{BrC}$ aerosols were also estimated. The fluorescence technique was adopted to further explore the components and possible chromophores

$85 \mathrm{in} \mathrm{BrC}$. The impacts of various sources and photooxidation on atmospheric $\mathrm{BrC}$ were unveiled by analyzing the relationships of $\mathrm{BrC}$ with chemical compositions and organic molecular markers of aerosols. This study provides a comprehensive view on the temporal variability in optical properties and sources of $\mathrm{BrC}$, helping to deepen the understanding in its climatic effects.

\section{Methods}

\subsection{Sample Collection}

$90 \quad \mathrm{PM}_{2.5}$ (Particulate matters with aerodynamic diameter $<2.5 \mu \mathrm{m}$ ) sampling was performed using a high-volume sampler (Tisch TE-PM $2.5 \mathrm{HVP}-\mathrm{BL})$ at a flow rate of $1.05 \mathrm{~m}^{3} \mathrm{~min}^{-1}$. The air sampler was equipped on the rooftop ( $20 \mathrm{~m}$ above ground level) of a building on the Weijinlu Campus of Tianjin University $\left(39.11^{\circ} \mathrm{N}, 117.17^{\circ} \mathrm{E}\right)$ in urban Tianjin. The sampling site is close to commercial and residential region, and there is no obvious industrial emission around the site. Field campaigns were conducted from 10 November to 23 December 2016 (winter) and from 22 May to 22 June 2017 (summer). Daytime samples

95 were collected from 08:00 to 20:00 LT, and nighttime samples were collected from 20:00 to 08:00 LT next day. Aerosols were collected onto quartz fiber filters with a size of $8 \times 10$ inch (Pallflex 2500QAT-UP), which were preheated at $450{ }^{\circ} \mathrm{C}$ for $6 \mathrm{~h}$ in a muffle furnace to remove potential contamination from organics. Field blank filters were also collected during both seasons 
by keeping blank filter in the sampler for 5 min without air flow. After collection, the samples were stored in the dark at $20{ }^{\circ} \mathrm{C}$ until analysis.

\subsection{Chemical Analysis}

Two pieces of quartz filters with diameter of $14 \mathrm{~mm}$ were punched and extracted with $25 \mathrm{~mL}$ ultrapure water $(>18.2 \mathrm{M} \Omega \mathrm{cm})$. The extracts were under ultrasonication for $20 \mathrm{~min}$ and then filtered through a poly tetra fluoroethylene (PTFE) syringe filter $(0.22 \mu \mathrm{m})$ to remove water-insoluble compounds. Concentrations of water-soluble organic carbon (WSOC) in the water extracts were determined with a TOC analyzer (TOC-VCPH, Shimadzu, Japan). The rest extracts were used for the light absorption and fluorescence measurement. A punch of quartz filter with an area of $\sim 2.3 \mathrm{~cm}^{2}$ was cut to measure the EC and OC concentrations in aerosol samples by a thermal-optical carbon analyzer (Model RT-4, Sunset, USA), following the National Institute for Occupational Safety and Health (NIOSH) protocol. Secondary organic carbon (SOC) was estimated with the EC tracer method (Castro et al., 1999). Major water-soluble inorganic ions (e.g., $\mathrm{SO}_{4}{ }^{2-}, \mathrm{NO}_{3}{ }^{-}, \mathrm{Cl}^{-}, \mathrm{NH}_{4}^{+}$, and $\mathrm{K}^{+}$) were analyzed with ion chromatography (ICS 5000+, Thermo, USA).

110 The measurements of molecular markers in organic aerosols have been reported in detail in our previous study (Fan et al., $2020 \mathrm{~b})$ and are briefly described here. First, a filter aliquot was extracted with dichloromethane/methanol (2:1; v/v) under ultrasonication for $10 \mathrm{~min}$ for three times. The extracts were then concentrated with a rotary evaporator, and dried with pure nitrogen gas. After that, $50 \mu \mathrm{L}$ of N,O-bis-(trimethylsilyl)trifluoroacetamide (BSTFA) with $1 \%$ trimethylsilyl chloride and 10 $\mu \mathrm{L}$ of pyridine was added to the extracts to react at $70{ }^{\circ} \mathrm{C}$ for $3 \mathrm{~h}$. After the polar groups were derivatized into the trimethylsilyl

115 (TMS) easters and ethers, the derivatives were added to $40 \mu \mathrm{L}$ of $n$-hexane-containing internal standards ( $\mathrm{C}_{13} n$-alkane, 1.43 $\mathrm{ng} \mu \mathrm{L}^{-1}$ ) before gas chromatography/mass spectrometry (GC/MS) analysis. GC/MS analysis was performed using an Agilent model $7890 \mathrm{GC}$ coupled to a 5975c mass-selective detector to identify and quantify organic compound classes. The GC was equipped with a split/splitless injector and a DB-5MS fused silica capillary column $(30 \mathrm{~m} \times 0.25 \mathrm{~mm}$ i.d. $0.5 \mu \mathrm{m}$ film thickness). The samples in the fused silica capillary column were analyzed using a specific GC temperature program with the carrier gas of helium. The MS was operated on electron impact (EI) mode at $70 \mathrm{eV}$, scanning from 50 to $650 \mathrm{Da}$. Data processes were performed with the Chemstation software. The results were corrected by field blanks, which were treated as the real samples. Temporal variations in concentrations of carbonaceous species and some molecular markers in $\mathrm{PM}_{2.5}$ including sugars and SOA tracers are plotted in Figure S1, S2, and S3, and seasonal average concentrations are summarized in Table S1.

\subsection{Light Absorption Analysis}

125 Light absorbance $\left(\mathrm{A}_{\lambda}\right)$ of the water extracts at the wavelength $(\lambda)$ spectra between 200 and $700 \mathrm{~nm}$ was measured with a UVVis spectrophotometer (UV2700, Shimadzu). Light absorption coefficient $\mathrm{Abs} \lambda\left(\mathrm{Mm}^{-1}\right)$ of the dissolved organic matter (DOM) at the wavelength $\lambda$ can be calculated as follows: 


$$
A b s_{\lambda}=\left(A_{\lambda}-A_{700}\right) \times \frac{V_{l}}{V_{a} \times L} \times \ln (10),
$$

where $V_{1}$ is the volume of the extracts, $V_{\mathrm{a}}$ is the volume of the punched and extracted air, and $L$ is the optical path length $(0.01$

$\mathrm{m}$ in this study). $A_{\lambda}$ are referenced to the $\mathrm{A}_{700}$ to account for any baseline drift (Hecobian et al., 2010). In this study, light absorption coefficients of water-soluble organics at $365 \mathrm{~nm}\left(\mathrm{Abs}_{365}\right)$ are used as proxy of $\mathrm{BrC}$ in accordance with previous studies (Laskin et al., 2015).

The mass absorption efficiency (MAE: $\mathrm{m}^{2} \mathrm{~g}^{-1}$ ) of water-soluble $\mathrm{BrC}$ can be derived as follows:

$$
M A E_{\lambda}=\frac{A b s_{\lambda}}{[W S O C]},
$$

135 where [WSOC] $\left(\mu \mathrm{gC} \mathrm{m}^{-3}\right)$ represents the mass concentration of WSOC.

The wavelength dependence of light absorption fits a power law as follows:

$$
A b s_{\lambda}=C \times \lambda^{-A A E},
$$

where $C$ is a concentration- and composition-related constant, and AAE is the absorption Ångström exponent depending on the types of chromophores. In this study, AAE was fitted at the range of $300-450 \mathrm{~nm}$.

140 The particle refractive index $(m=n+k$ i) is a key optical parameter in climate model expressing the light extinction ability of ambient aerosols. The imaginary part $k$ represents light absorption and can be estimated from MAE as follows (Liu et al., 2013):

$$
k_{\lambda}=\frac{\lambda \times \rho \times A b s_{\lambda}}{4 \pi \times[W S O C]}=\frac{\lambda \times \rho \times M A E_{\lambda}}{4 \pi},
$$

where $\rho\left(\mathrm{g} \mathrm{m}^{-3}\right)$ is particle density and assumed as 1.5 according to Liu et al. (2013).

\section{2.4 Determination of Direct Radiative Absorption by BrC}

The direct radiative forcing of $\mathrm{BrC}$ in Tianjin was assessed with the simple forcing efficiency (SFE). SFE ( $\mathrm{W} \mathrm{g}^{-1}$ ) represents the energy added to the Earth-atmosphere system by per unit mass aerosol (Bond and Bergstrom, 2006). The wavelengthdependent SFE of BrC can be calculated as follows (Chen and Bond, 2010):

$$
\frac{d \mathrm{SFE}}{d \lambda}=-\frac{1}{4} \frac{d S(\lambda)}{d \lambda} \tau_{a t m}^{2}(\lambda)\left(1-F_{c}\right)\left[2\left(1-a_{s}\right)^{2} \beta(\lambda) \operatorname{MSE}(\lambda)-4 a_{s} \operatorname{MAE}(\lambda)\right],
$$

150 where $d \mathrm{~S}(\lambda) / d \lambda$ is the wavelength-dependent solar irradiance, $\tau_{\mathrm{atm}}$ is the atmospheric transmission $(0.79), F_{\mathrm{c}}$ is the cloud fraction (0.6), $\alpha_{\mathrm{s}}$ is the surface albedo ( 0.19 for global average), $\beta$ is the backscatter fraction, and MSE and MAE are the mass scattering and absorption efficiency of $\mathrm{BrC}$, respectively. 
Direct radiative forcing due to aerosol scattering can be ignored when estimating the radiative effects of BrC light absorption. Therefore, the absorption radiative forcing in a given spectral range was calculated by integrating the SFE values per nanometer

$$
S F E=\int \frac{d S(\lambda)}{d \lambda} \tau^{2}(\lambda)\left(1-F_{c}\right) a_{s} \operatorname{MAE}(\lambda) d \lambda,
$$

In addition, the relative direct climate warming effects due to $\mathrm{BrC}$ light absorption were also estimated by comparing the direct radiative forcing of $\mathrm{BrC}$ with that of $\mathrm{BC}$ (Bosch et al., 2014; Kirillova et al., 2014). Relative radiative forcing of $\mathrm{BrC}\left(f_{\mathrm{BrC}}\right)$ is calculated with the method as follows:

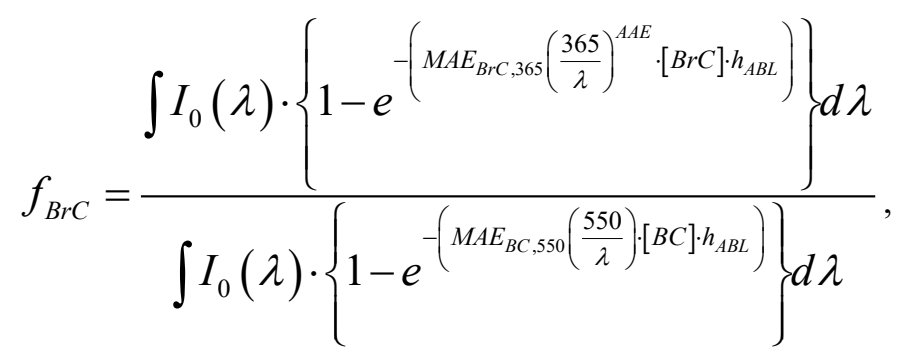

where $\mathrm{I}_{0}(\lambda)$ is the solar emission spectrum estimated using the clear sky Air Mass 1 Global Horizontal (AM1GH) irradiance model (Levinson et al., 2010); $\mathrm{MAE} \mathrm{BC}_{\mathrm{BC}, 550}$ is the mass absorption efficiency for $\mathrm{BC}$ at $550 \mathrm{~nm}$, which is set to $7.5 \mathrm{~m}^{2} \mathrm{~g}^{-1}$ and the AAE for BC is set to 1 based on Bond and Bergstrom (2006) and Kirillova et al. (2014); [BC] is the mass concentration of $\mathrm{BC}$; The height of the atmospheric boundary layer $\left(h_{\mathrm{ABL}}\right)$ is adopted as $1000 \mathrm{~m}$ because it has little impact on the calculated ratio in the range of 200-3000 $\mathrm{m}$ (Kirillova et al., 2014).

\subsection{Fluorescence Analysis}

The EEM fluorescence spectra of the extracts were measured using a fluorometer (Aqualog, Horiba). The excitation wavelength range was $240-550 \mathrm{~nm}$ ( $3 \mathrm{~nm}$ interval), and the emission wavelength range was $246-828 \mathrm{~nm}(\sim 2.4 \mathrm{~nm}$ interval). The measured EEM spectra were calibrated by instrument calibration, internal filter correction and Raman correction (Murphy et al., 2013). The EEM spectra of all samples were corrected by subtracting the blank sample. The fluorescence intensities were further divided by the amount of water used for the extraction and the air volume of each filter sample to convert the fluorescence unit to $\mathrm{RU} \mathrm{m}{ }^{-3}$. The fluorescence properties of the extracts were determined through humification index (HIX), biological index (BIX), and fluorescence index (FI). FI was determined by the ratio of emission intensity of 450 to $500 \mathrm{~nm}$ under the excitation wavelength of $370 \mathrm{~nm}$, BIX was determined by the ratio of emission intensity of $380 \mathrm{~nm}$ to $430 \mathrm{~nm}$ under the excitation wavelength of $310 \mathrm{~nm}$, HIX was determined by the ratio of the integrated fluorescence emission intensity in the range of 435-480 nm to 300-345 $\mathrm{nm}$ under the excitation wavelength of $255 \mathrm{~nm}$ (Battin, 1998; McKnight et al., 2001). With the fully corrected and treated EEM fluorescence spectra data, the parallel factor analysis (PARAFAC) model was adopted to identify the fluorescent components of $\mathrm{BrC}$ (Murphy et al., 2013). PARAFAC is a mathematical method to separate chemically 
independent but spectrally overlapping fluorescent components based on assumption that EEM spectra are independent, liner related, and additive (Murphy et al., 2011). During the recent years, PARAFAC model has been used to investigate The fluorescence properties of aerosol WSOC (Pöhlker et al., 2012; Matos et al., 2015; Chen et al., 2016, 2020; Wu et al., 2019, 2020b; Dey et al., 2021). The PARAFAC modeling was performed with the software package Solo (Eigenvector Inc.).

\subsection{Source apportionment of $\mathrm{BrC}$}

Positive Matrix Factorization (PMF, version 5.0), a receptor model developed by the United States Environmental Protection

185 Agency (USEPA), was adopted to carry out the source apportionment of $\mathrm{BrC}$. PMF model is a multivariate factor analysis tool that decomposes a measured sample matrix into two matrices including factor profiles and factor contributions (Paatero and Tapper, 1994). PMF can provide as model outcome both the source profiles and contributions of various sources without inputting source profiles. In this study, the measurement data of $\mathrm{BrC}$ (i.e., Abs365) and chemical species of the aerosol samples, including OC, WSOC and major inorganic ions, were selected as inputs of PMF model. Especially, the organic molecular

190 markers (i.e., sugars, biogenic and anthropogenic SOA compounds) were implemented to the PMF model to constrain the sources of BrC. Separating and identifying different source factors with molecular markers species enables more accurate and finer results of source apportionment of organic aerosols (Wang et al., 2017; Al-Naiema et al., 2018; Li et al., 2020d).

\section{Results and Discussion}

\subsection{Light Absorption Properties of BrC}

195 The variations in light absorption coefficients of water-soluble $\mathrm{BrC}$ with wavelength in the spectral range of 300-600 nm in winter and summer in Tianjin are presented in Figure S4. The absorption spectrums showed an evident feature of BrC, since they were highly wavelength-dependent and decreased remarkably from the ultraviolet to the visible ranges. BrC light absorption was more wavelength-dependent in winter than in summer, since the winter average AAE of BrC was 5.4 \pm 0.4 , about $10 \%$ higher than the summer average $(4.9 \pm 0.6)$ (Table 1). However, AAE in summer varied in a relatively wider range

200 (3.2-6.5) compared with that in winter (4.3-6.1) (Figure 1a). The gap between AAE values in different seasons indicate the distinct chemical composition of $\mathrm{BrC}$ resulted from various sources and atmospheric formation/aging processes. $\mathrm{BrC}$ in winter may be significantly affected by primary emissions of fossil fuel combustion, since high AAE coefficients are often associated with biomass burning (Desyaterik et al., 2013) and coal combustion (Li et al., 2019). In contrast to the significant seasonal variations, there were no evident diurnal variations in AAE, because daytime AAE values (4.8 \pm 0.6 in summer and $5.4 \pm 0.4$

205 in winter) were comparable with nighttime AAE values ( $4.9 \pm 0.6$ in summer and $5.4 \pm 0.3$ in winter). $t$-test results also showed that the day/night differences in $\mathrm{AAE}$ values were not significant. It indicates that chemical compositions of $\mathrm{BrC}$ in daytime and nighttime may be similar. 
Water-soluble BrC light absorption (at $365 \mathrm{~nm}$ ) (i.e., Abs365) in Tianjin experienced obvious day-to-day variations in both winter and summer (Figure 1b). Exhibiting remarkable seasonal variations, Abs 365 values were much larger in winter than in summer, similar to the concentrations of WSOC and OC (Table S1). Abs 365 was in the range of 2.0-53.7 $\mathrm{Mm}^{-1}$ in winter and 0.5-6.1 Mm $\mathrm{Mm}^{-1}$ in summer. The average $\mathrm{Abs}_{365}$ was $14.1 \pm 8.5 \mathrm{Mm}^{-1}$ in winter, $\sim 6.7$ times higher than the summer average (2.1 $\pm 1.0 \mathrm{Mm}^{-1}$ ) (Table 1). Generally, there are no significant differences between daytime and nighttime $\mathrm{Abs}_{365}$, with the daytime averages of $14.4 \pm 10.3 \mathrm{Mm}^{-1}$ (winter) and $2.0 \pm 0.8 \mathrm{Mm}^{-1}$ (summer) and nighttime averages of $13.9 \pm 6.3 \mathrm{Mm}^{-1}$ (winter) and $2.1 \pm 1.1 \mathrm{Mm}^{-1}$ (summer). Temporal variations in $\mathrm{BrC}$ light absorption are closely related to both the abundance and absorption capacity of BrC.

MAE can be used to describe the light absorbing ability of $\mathrm{BrC}$ aerosols. $\mathrm{MAE}_{365}$ values of water-soluble $\mathrm{BrC}$ in winter and summer were in the ranges of 1.06-2.58 $\mathrm{m}^{2} \mathrm{~g}^{-1}$ and $0.36-1.50 \mathrm{~m}^{2} \mathrm{~g}^{-1}$, respectively (Figure 1c). Average MAE 365 in winter $\left(1.54 \pm 0.33 \mathrm{~m}^{2} \mathrm{~g}^{-1}\right)$ was $\sim 1.8$ times higher than that in summer $\left(0.84 \pm 0.22 \mathrm{~m}^{2} \mathrm{~g}^{-1}\right)$, suggesting the much higher light absorption capacity of $\mathrm{BrC}$ in winter than in summer (Table 1). The imaginary refractive index, $k$, is a vital parameter representing the light-absorbing ability used in climate model to assess direct radiative forcing of aerosols (Andreae and Gelencsér, 2006; Shamjad et al., 2016). $k_{365}$ for water-soluble $\mathrm{BrC}$ in Tianjin were in the range of $0.052-0.127$ in winter and $0.018-0.074$ in summer, with the seasonal averages of $0.076 \pm 0.016$ and $0.041 \pm 0.011$, respectively (Table 1). The obvious seasonal variations in both $\mathrm{MAE}_{365}$ and $k_{365}$ also suggest the distinct sources and formation mechanisms of $\mathrm{BrC}$ chromophores in different seasons. In contrast, although the nighttime light-absorbing ability was slightly stronger than in daytime in both seasons, diurnal differences were not statistically significant between daytime and nighttime $\mathrm{MAE}_{365}$ (and $k_{365}$ ) as revealed by $t$-test, also indicating the similar chemical compositions of $\mathrm{BrC}$ in daytime and nighttime. $\mathrm{MAE}_{365}$ values in Tianjin were comparable with those in Beijing in North China (Yan et al., 2015), higher than those in the US (Xie et al., 2019) and Europe (Moschos et al., 2018), and lower than those in New Delhi and Kanpur in India (Dasari et al., 2019; Choudhary et al., 2021).

\subsection{Direct Radiative Absorption by BrC}

Radiative forcing efficiency of water-soluble $\mathrm{BrC}$ was estimated by integrating the wavelength-dependent SFE from 300 to $700 \mathrm{~nm}$ (i.e., $\mathrm{SFE}_{300-700}$ ). Because $\mathrm{BrC}$ mainly absorb solar radiation in the $\mathrm{UV}$ spectral region, the $\mathrm{BrC}$ absorption radiative forcing efficiency in the $300-400 \mathrm{~nm}$ range (i.e., $\mathrm{SFE}_{300-400}$ ) was also calculated. Figure 1d illustrates the temporal variations in the radiative forcing efficiencies of $\mathrm{BrC}$ at the two spectra. In summer, $\mathrm{SFE}_{300-400}$ and $\mathrm{SFE}_{300-700}$ varied from 0.6 to $2.4 \mathrm{~W}$ $\mathrm{g}^{-1}$ and 1.7 to $10.5 \mathrm{~W} \mathrm{~g}^{-1}$, respectively. By comparison, variations in the forcing efficiencies were slightly larger in winter, and

$\mathrm{SFE}_{300-400}$ and $\mathrm{SFE}_{300-700}$ varied from 1.6 to $3.6 \mathrm{~W} \mathrm{~g} \mathrm{~g}^{-1}$ and 3.3 to $13.4 \mathrm{~W} \mathrm{~g}^{-1}$. Average BrC forcing efficiency in winter (summer) were $6.2 \pm 2.0 \mathrm{~W} \mathrm{~g}^{-1}\left(4.6 \pm 1.7 \mathrm{~W} \mathrm{~g}^{-1}\right)$ over the entire solar spectrum and $2.4 \pm 0.5 \mathrm{~W} \mathrm{~g}^{-1}\left(1.4 \pm 0.4 \mathrm{~W} \mathrm{~g}^{-1}\right)$ in the UV range (Table 1). $\mathrm{SFE}_{300-400}$ and $\mathrm{SFE}_{300-700}$ were $\sim 71 \%$ and $\sim 35 \%$ larger in winter than summer, respectively, indicating the more abundant $\mathrm{BrC}$ with stronger light-absorbing capacity resulted in a remarkable increase in direct radiative forcing by $\mathrm{BrC}$. It should be noted that $\mathrm{SFE}_{300-400}$ accounted for $22.4-57.4 \%(40.3 \pm 6.4 \%)$ and $21.0-52.0 \%(30.7 \pm 5.8 \%)$ of $\mathrm{SFE}_{300-700}$ in winter and summer, respectively, suggesting radiative forcing in the UV range plays a vital role in radiative forcing by $\mathrm{BrC}$ 
absorption. Comparing with the limited literature, the BrC forcing efficiency in Tianjin was slightly larger than that in Hong Kong (4.4 $\mathrm{W} \mathrm{g}^{-1}$ in winter, Zhang et al., 2020b), while much smaller than that in Xi'an in Northwest China (11.7 $\mathrm{W} \mathrm{g}^{-1}$ in winter, Zhang et al., 2020b) and Kanpur in India (19.2 $\mathrm{W} \mathrm{g}^{-1}$ in winter and $12.3 \mathrm{~W} \mathrm{~g}^{-1}$ in monsoon, Choudhary et al., 2021). Direct radiative forcing by $\mathrm{BrC}$ absorption was also evaluated by calculating solar radiative effect of water-soluble $\mathrm{BrC}$ relative to $\mathrm{BC}$ in the $280-4000 \mathrm{~nm}$ range (i.e., $f_{280-4000}$ ). Relative radiative effect of $\mathrm{BrC}$ in the $\mathrm{UV}$ spectral region (i.e., $f_{300-400}$ ) was also calculated. $f_{280-4000}$ was in the ranges of $4.5-25.3 \%$ and $4.8-25.6 \%$ (Figure 1e), with the comparable averages of $13.5 \pm$ $4.1 \%$ and $12.5 \pm 4.5 \%$ in winter and summer (Table 1), respectively, indicating that water-soluble $\mathrm{BrC}$ is a non-negligible contributor to the climate warming by absorbing solar radiation. Although $\mathrm{BrC}$ light absorption was much stronger in winter than summer, relative direct radiative effects of $\mathrm{BrC}$ at the entire solar spectrum were comparable in the two seasons. It can be attributed to the enhanced direct radiative effect by $\mathrm{BC}$ absorption due to the sharp increase in $\mathrm{BC}$ concentration in winter (Table S1). Relative direct radiative effect in the UV range $\left(f_{300-400}\right)$ were in the ranges of $19.0-96.1 \%$ and $17.4-76.6 \%$ in winter and summer, respectively. $f_{300-400}$ exhibited obvious seasonal variations with a much larger value in winter $(54.3 \pm$ $16.9 \%$ ) than in summer $(44.6 \pm 13.9 \%)$. The much larger $f_{300-400}$ compared with $f_{280-4000}$ suggested that although BC still dominated radiative effect by light-absorbing carbonaceous aerosols, $\mathrm{BrC}$ played a far more important role in the shorter wavelength in comparison to the entire spectrum. The large contributions of $\mathrm{BrC}$ light absorption in the UV spectral range deserve more attentions due to its potential impact on atmospheric photochemistry and ozone formation (Mok et al., 2016; Baylon et al., 2018). Relative direct radiative effects of water-soluble $\mathrm{BrC}$ in Tianjin were comparable to those in High Arctic $(13 \pm 7 \%$ ) (Yue et al., 2019a), and much larger than those in other urban locations in China such as Beijing (5.7 $\pm 2.5 \%$ in summer and $10.7 \pm 3.0 \%$ in winter) (Yan et al., 2015), and Xi' an ( $2 \pm 1 \%$ in summer and $10 \pm 4 \%$ in winter) (Huang et al., 2018).

\subsection{Fluorescence Indices of $\mathrm{BrC}$}

Fluorescence indices originally developed as indicators of the type and source of the fluorescent DOM in aquatic systems and soils have been applied to investigate the sources and aging processes of organic aerosols for a decade (Mladenov et al., 2011; Lee et al., 2013; Fu et al., 2015; Qin et al., 2018; Tang et al., 2021; Wu et al., 2021). HIX is a proxy for the aromaticity of

265 DOM and an increased HIX value is usually accompanied a higher polycondensation degree, $\mathrm{C} / \mathrm{H}$ ratio, and aromaticity of DOM (Zsolnay et al., 1999; McKnight et al., 2001; Birdwell and Engel, 2010). HIX values in this study were $2.22 \pm 0.54$ (1.17-3.51) and $2.73 \pm 0.51$ (1.64-3.96) during winter and summer, respectively (Figure if and Table 1), suggesting that water-soluble organic aerosols were less aromatic compared with aquatic or soil DOM, which might be attributed to the lower molecular weight and smaller contributions from aromatic organics (Qin et al., 2018). HIX values of Tianjin aerosols were comparable to those of aerosols in Mt. Tai, North China (1.7-3.4, 2.4) (Yue et al., 2019b) and the Colorado Rocky Mountains, USA (0.72-4.75, 2.42) (Xie et al., 2016), lower than those in Indo-Gangetic Plain, India (4.8 \pm 0.3 ) (Dey et al., 2021), Bangkok, Thailand (3.4 \pm 0.99) (Tang et al., 2021) and the high Arctic (0.69-5.24, 2.93) (Fu et al., 2015), and higher than those in Lanzhou, China (1.2 in winter and 2.0 in summer) (Qin et al., 2018), suggesting the moderate aromaticity degree of water- 
soluble BrC in Tianjin. Similar to previous research in Lanzhou, Northwest China (Qin et al., 2018), HIX values in Tianjin experienced obvious seasonal variations with higher values in summer than winter, suggesting that water-soluble $\mathrm{BrC}$ in summer had a higher aromaticity degree or increasing polycondensation in chemical structure (Zsolnay et al., 1999). Low HIX values were probably associated with freshly introduced primary organic aerosols and fresh secondary organic aerosols (SOA); however, HIX values would significantly increase during the aging processes of organic aerosols (Lee et al., 2013; Tang et al., 2021). Therefore, HIX values indicated that $\mathrm{BrC}$ in Tianjin were significantly affected by primary emissions and less aged in winter, while more aged in summer due to the strong photooxidation and secondary chemical processes.

FI and BIX were both adopted to assess the relative contributions from biological sources to DOM. The fluorophore is often associated with higher aromaticity if FI is low, and vice versa (McKnight et al., 2001; Fu et al., 2015). High BIX usually corresponds to the predominant biological or microbial materials, while low BIX indicates few biological organics (Huguet et al., 2009). For water-soluble BrC in Tianjin, BIX values were $1.32 \pm 0.14(1.08-1.73)$ and $1.19 \pm 0.13(0.92-1.45)$ in winter and summer, and the corresponding FI values were $1.71 \pm 0.06(1.60-1.88)$ and $1.61 \pm 0.10(1.32-1.82)$, respectively (Figure $1 \mathrm{~g}-\mathrm{h}$ and Table 1). The slightly lower summer values of BIX and FI indicate that fluorescent BrC aerosols in summer had higher aromaticity degrees, in accordance with the HIX results. The lower FI values in summer may be a result of photobleaching of fluorescent DOM, since fluorescent DOM absorbing light at higher wavelengths would be removed due to photochemical processes (McKnight et al., 2001; Xie et al., 2016). Another possible reason for the higher BIX and FI values in winter was that primary aerosols from coal combustion and biomass burning had high FI and BIX values (Tang et al., 2021). Table 1 also shows that in both seasons BIX and FI values were slightly lower at daytime compared with nighttime, suggesting that fluorophores in aerosols at daytime were more aged due to photobleaching and thus had higher aromaticity.

Figure 1 presents an obvious seesaw relationship between HIX and BIX (or FI) in winter. HIX showed significantly negative correlations with both FI $(R=-0.803, p<0.01)$ (Figure 2a) and BIX $(R=-0.927, p<0.01)$ (Figure 2b) in winter, indicating the quite similar factors controlling aromaticity and biological contribution of organic aerosols. Actually, the elevated aromaticity in winter were mainly led by the increased aromatic compounds (e.g., polycyclic aromatic hydrocarbons (PAHs)), which were mostly emitted from anthropogenic sources. Therefore, higher aromaticity degrees were generally associated with larger contribution from anthropogenic sources while smaller contribution from biological activities. However, in summer, correlations of HIX with FI $(R=-0.207, p>0.05)$ or and $(R=-0.130, p>0.05)$ were not significant, suggesting the different

300 influencing factors of aromaticity and biological contribution during the period. For example, secondary formation and aging processes play an important role in the hot season due to the stronger radiation and higher temperature, which may result in increases in both HIX and BIX, although the influences on BIX are relatively small (Lee et al., 2013). Comparison of HIX as a function of FI and BIX for Tianjin aerosols together with aerosol samples in literature are summarized in Figure 2c and 2d, respectively. HIX values for Tianjin aerosols mainly concentrated in the region where freshly emitted aerosols (Mladenov et 305 al., 2011) and fresh SOA (Lee et al., 2013) located, but they were much lower than HIX values for aged SOA (Lee et al., 2013) and aged dust aerosols experiencing long-range transport (Mladenov et al., 2011). BIX and FI values of aerosols in Tianjin were mainly located within the region where the primary aerosols from biomass burning, coal combustion, and vehicle 
emissions concentrated (Tang et al., 2021). Therefore, the fluorescence indices together indicated water-soluble BrC in Tianjin prominently contained freshly emitted and less aged aerosol, especially in winter. However, since the influencing mechanisms of fluorescence properties of atmospheric organic compounds are extremely complicated and still unclear, further studies on fluorescence indices are needed (Wu et al., 2021).

\subsection{Fluorescent Components of $\mathrm{BrC}$}

To explore the possible sources and controlling factors of fluorescent $\mathrm{BrC}$, correlations of fluorescent intensities with light absorption and chemical compositions of aerosols were examined. Generally, fluorescent intensities were strongly correlated with $\operatorname{Abs}_{365}$ in both winter $(R=0.863, p<0.01)$ and summer $(R=0.882, p<0.01)$, suggesting that the affecting mechanisms of light absorption and fluorescent properties were much similar and a majority of light-absorbing $\mathrm{BrC}$ aerosols were fluorescent (Figure S5a). The strong correlations of fluorescent intensities with $\mathrm{EC}(R=0.743-0.841, p<0.01)$ (Figure S5b) and SOC $(R=0.484-0.820, p<0.01)$ (Figure S5c) suggested the combined effects of combustion-related sources and secondary formation processes on $\mathrm{BrC}$ fluorophores. Note that fluorescent intensities even showed a stronger correlation with SOC than EC in winter, indicating the dominant source of fluorescent $\mathrm{BrC}$ might be secondary aerosols rather than primary emissions from combustion in this season. Levoglucosan, the tracer of biomass burning (Simoneit, 2002), also strongly correlated with fluorescent intensities (Figure S5d), suggesting that biomass burning was an important source of fluorescent $\mathrm{BrC}$. The contribution of biomass burning to aerosol fluorophores is also suggested by previous studies (Qin et al., 2018; Xie et al., 2020; Dey et al., 2021)

325 Figure 3a presents typical EEM fluorescence spectra of water-soluble fluorophores in $\mathrm{PM}_{2.5}$ samples in winter and summer in Tianjin, respectively. PARAFAC analysis on the basis of EEM spectra was conducted to provide more knowledge of the chemical composition and source of $\mathrm{BrC}$ fluorophores. Five independent fluorescent components in water-soluble $\mathrm{BrC}$ were identified by PARAFAC model with the total explained variance of $99.65 \%$ within the whole sampling period (Figure $3 b$ ). Figure $3 \mathrm{c}$ presents the emission and excitation spectra of each component at peak emission and excitation wavelengths. The fluorescent intensities of water-soluble $\mathrm{BrC}$ with relative abundances of each fluorescent component varied for different samples (Figure S6), suggesting that the chemical compositions of fluorescent organic matters were highly variable. The fluorophore $\mathrm{C} 1$ presents a primary fluorescent peak at Excitation/Emission (Ex/Em) of $\sim 250 \mathrm{~nm} / 395 \mathrm{~nm}$ and secondary peak at $\mathrm{Ex} / \mathrm{Em}$ of $\sim 315 \mathrm{~nm} / 395 \mathrm{~nm}$. C1 can be classified as a humic-like fluorophore because the bimodal distribution of fluorescence spectra is typically associated with humic-like substance (HULIS) (Coble, 2007; Murphy et al., 2011; Yu et al., 2015). The second peak at the high excitation wavelength suggests there are plenty of condensed aromatic moieties, conjugated bonds and nonlinear ring systems (Matos et al., 2015). The fluorophore $C 2$ exhibiting a peak at Ex/Em of $\sim 250 \mathrm{~nm} / 465 \mathrm{~nm}$ is also a humic-like fluorophore. The longer wavelength of $\mathrm{C} 2$ suggests that compared with $\mathrm{C} 1, \mathrm{C} 2$ is more aromatic with higher molecular weight, containing more conjugated and unsaturated chemical structures due to condensation reactions (Matos et al., 2015; Fan et al., 2020a; Dey et al., 2021). C3 showing a peak at Ex/Em of $\sim 250 \mathrm{~nm} / 385 \mathrm{~nm}$ is also a humic-like fluorophore 
containing lowly-oxygenated organic species and $\mathrm{C} 1$ is more oxidized than $\mathrm{C} 3$; however, $\mathrm{C} 2$ is associated with highlyoxygenated structures (Elcoroaristizabal et al. 2014; Chen et al., 2016).

The other two fluorescent components (i.e., C4 and C5) present different spectral features from the humic-like fluorophores, and they are identified as protein-like fluorophores due to their short emission wavelengths (Coble, 1996, 2007). C4 showing

345 a fluorescence peak at Ex/Em of $\sim 250 \mathrm{~nm} / 340 \mathrm{~nm}$ is often associated with tryptophan-like fluorophore (Murphy et al., 2011, 2013). C5 with a peak at Ex/Em of $\sim 275 \mathrm{~nm} / 305 \mathrm{~nm}$ is generally regarded as a typical tyrosine-like fluorophore (Stedmon and Markager, 2005; Murphy et al., 2011). The significant correlations between BIX and C4 $(R=0.583, p<0.01)$ or $\mathrm{C} 5(R=$ $0.369, p<0.01$ ) may support the possible contributions of bioaerosols to the protein-like compounds in the components (Figure $\mathrm{S} 7 \mathrm{a}$ and S7b). It should be noted that due to the similar fluorescence spectra, the two protein-like fluorophores are also probably related to some PAHs-like or phenol-like species from fossil fuel combustion and biomass burning, which is particularly in the case of urban aerosols (Elcoroaristizabal et al. 2014; Matos et al., 2015; Chen et al., 2020). For example, to a certain extent the spectrum of $\mathrm{C} 4$ is overlapped with that of naphthalene, an aromatic compound from fossil fuel combustion (Mladenov et al., 2011; Wu et al., 2019). Another evidence supporting the likely impacts of fossil-fuel combustion activities on the two protein-like components in $\mathrm{BrC}$ is the strong correlations of low molecular weight $n$-alkanes with both $\mathrm{C} 4(R=0.880, p<0.01)$ and C5 $(R=0.842, p<0.01)$ (Figure S7c and S7d), since low molecular weight $n$-alkanes were mainly derived from emissions of incomplete combustion of fossil fuels (Xie et al., 2009). Furthermore, C5 produces spectra similar to the fluorophore which may be related to non-nitrogen-containing species (Chen et al., 2016).

Correlation coefficients were further obtained between fluorescent intensities of each PARAFAC component and chemical compositions to identify the sources of different fluorophores. During the sampling periods, EC showed significantly strong correlations with all the fluorescent components, except C5 in summer (Figure 4a1 and 4b), again providing support to the influence of primary emissions from combustion-related sources on $\mathrm{BrC}$ fluorophores. Similarly, the relationships between levoglucosan and $\mathrm{BrC}$ fluorophores suggest that biomass burning contributed to the formation of all the humic-like and proteinlike fluorophores except C5 in summer (Figure 4c and 4d). Correlation between C5 and EC in summer was weak $(R=0.198$, $p<0.01)$, and that between $\mathrm{C} 5$ and SOC was comparatively stronger $(R=0.326, p<0.01)$, indicating that combustion processes

365 were not the dominant sources of $\mathrm{C} 5$ in summer and secondary formation even played a more important role. The considerable impacts of secondary formation on fluorescent $\mathrm{BrC}$ were indicated by the significant correlations between SOC and all the components, especially in winter (Figure $4 \mathrm{e}$ and $4 \mathrm{f}$ ). It is noted that $\mathrm{C} 2$ presented the strongest correlation with SOC among the humic-like fluorophores, followed by $\mathrm{C} 1$ and $\mathrm{C} 3$. This finding supported the hypothesis that $\mathrm{C} 2$ is associated with highlyoxygenated structures, while $\mathrm{C} 3$ is less oxidized than the lowly-oxygenated component $\mathrm{C} 1$.

370 Figure 5 illustrate the average relative contributions of the fluorescent components for water-soluble $\mathrm{BrC}$ in different periods. On average, the humic-like fluorophores together contributed $73.4 \%$ and $68.7 \%$ to the fluorescence intensity in winter and summer, respectively, suggesting that humic-like fluorophores played a dominant role in fluorescence properties of watersoluble BrC in Tianjin. Generally, for winter samples, the lowly-oxygenated fluorophores C1 (27.5\%) and C3 (24.4 \%) both made considerable contributions, followed by the highly-oxygenated fluorophore $\mathrm{C} 2$ (21.5\%). By contrast, in summer, relative 
contribution made by the least-oxidized component $\mathrm{C} 3$ remarkably decreased to $8.6 \%$. Meanwhile, $\mathrm{C} 1$ presented much more abundant (35.8 \%) and C2 also slightly increased (24.3\%). The larger relative contributions of more-oxygenated fluorophores in summer might partly attribute to the reason that the lowly-oxygenated fluorophores would be photodegraded through exposure to the strong summer solar radiation and then convert into more-oxygenated fluorophores through the oxygenation reaction pathways. This can further support the results that $\mathrm{BrC}$ were more aged in summer than in winter, which were previously revealed by the fluorescent indices. In addition, this photoinduced mechanism can also explain the diurnal variations in relative abundances of humic-like fluorophores, which was characterized by smaller contribution of the lowly-oxygenated fluorophore $\mathrm{C} 3$ and larger contribution of the highly-oxygenated fluorophore $\mathrm{C} 2$ in daytime than nighttime in both seasons. Protein-like fluorophores were also vital components for fluorescent $\mathrm{BrC}$ since the two components together accounted for $26.6 \%$ and $31.3 \%$ of the total fluorescence intensities in winter and summer, respectively (Figure 5). One possible reason for the larger contribution of protein-like fluorophores during summertime is the higher relative abundances of bioaerosols from fungal spores and plant debris due to the enhanced biological activities in summer, which can be supported by our previous research (Fan et al., 2020b). C4, the component significantly influenced by combustion sources, made a much smaller contribution in summer (12.4\%) compared with winter (20.7\%). However, C5 contributed $18.9 \%$ in summer, more than three times larger than in winter (5.9\%). This is not surprising since $\mathrm{C} 5$ had fluorescent spectra similar to that of a photochemicallyformed fluorophore (Chen et al., 2020). Therefore, the larger contribution of C5 was likely due to the excessive oxidation and decomposition processes in summer, and this was particularly the case in daytime.

\subsection{Sources of BrC}

Relationships between $\mathrm{BrC}$ light absorption and carbonaceous species of aerosols were examined to investigate the sources of $\mathrm{BrC}$ in Tianjin (Figure 6a-d). Temporal pattern of $\mathrm{Abs}_{365}$ was quite similar to that of WSOC (Figure S1a) and OC (Figure S1b).

395 The strongly positive correlations between $\mathrm{Abs}_{365}$ and WSOC $(R=0.837-0.947, p<0.01$, Figure 6a) and OC $(R=0.851-$ $0.956, p<0.01$, Figure $6 \mathrm{~b}$ ) indicates that the sources of $\mathrm{BrC}$ were similar to those of WSOC and OC. Abs 365 also well correlated with EC $(R=0.695-0.789, p<0.01$, Figure $6 \mathrm{c})$, suggesting that the combustion-related processes were important sources of ambient $\mathrm{BrC}$ in both seasons, since $\mathrm{EC}$ is mainly from incomplete combustion of biomass and fossil fuels. We have found that biomass burning was one of the most abundant sources of OC in Tianjin, especially in winter (Fan et al., 2020b). Abs 365 was

400 significantly correlated with levoglucosan $(R=0.498-0.665, p<0.01)$, the typical organic molecular tracer of biomass burning, indicating that a considerable fraction of $\mathrm{BrC}$ aerosols were associated with biomass burning activities in both winter and summer (Figure 6e). This is in accordance with previous findings that biomass burning is an important source of atmospheric BrC (Lack et al., 2012; Lin et al., 2016). Levoglucosan concentration in winter (252 $\pm 145 \mu \mathrm{g} \mathrm{m}^{-3}$ ) was more than 10 times larger than that in summer $\left(23.6 \pm 34.4 \mu \mathrm{g} \mathrm{m}^{-3}\right)$, suggesting the much larger contribution of biomass burning to winter OC and

$405 \mathrm{BrC}$ (Table S1). The influences of biomass burning on $\mathrm{BrC}$ can also be supported by the strong linear correlations of $\mathrm{Abs} 365$ with $\mathrm{K}^{+}\left(R=0.784-0.789, p<0.01\right.$, Figure 6f), since $\mathrm{K}^{+}$is another tracer of biomass burning. However, the relatively weaker correlation between $\mathrm{Abs}_{365}$ and levoglucosan in winter in comparison with that in summer indicates the relative contribution 
of biomass burning might be smaller in winter. It is not surprising because combustion of fossil fuel such as coal and petroleum played a more important role in winter $\mathrm{BrC}$ formation due to the intense anthropogenic activities (e.g., heating) in cold season. This can be supported by the much stronger linear correlations of $\mathrm{Abs}_{365}$ with $\mathrm{SO}_{4}{ }^{2-}(R=0.812, p<0.01$, Figure $6 \mathrm{~g})$ and $\mathrm{NO}_{3}{ }^{-}$ $(R=0.769, p<0.01$, Figure $6 \mathrm{~h})$ in winter, since the precursors of $\mathrm{NO}_{3}{ }^{-}$(e.g., $\left.\mathrm{NO}_{x}\right)$ and $\mathrm{SO}_{4}{ }^{2-}$ (e.g., $\left.\mathrm{SO}_{2}\right)$ are mainly emitted from fossil-fuel combustion. Such results coincide with previous studies which found that fossil-fuel combustion made great contributions to winter aerosols in Tianjin (Huang et al., 2017; Gao et al., 2018).

Relationships between Abs365 and molecular markers of organic aerosols from other specific emission sources were analyzed to investigate the potential sources of atmospheric BrC. Besides primary emissions from combustions, bioaerosols, which contain various particle types such as bacteria, algae, pollen, fungal spores, plant debris and biopolymers, are also important sources of BrC aerosols (Andreae and Gelencsér, 2006; Pöhlker et al., 2013). Many sugar compounds are emitted persistently from biological sources and have been viewed as tracers of primary bioaerosols (Hu et al., 2020). For example, arabitol and mannitol are the major species in fungi and therefore used as the tracer for airborne fungal spores (Bauer et al., 2008); glucose is predominantly derived from terrestrial vegetative fragments such as pollen, fruit, and debris (Pacini, 2000); trehalose, a metabolite of many microorganisms, is also frequently recognized as fungal carbohydrates (Simoneit, 2004); xylose, a monosaccharide, is the main component of hemicellulose in biomass and comes from different sources such as bacteria, vegetation, microbiota and biomass burning (Wan et al., 2019). Therefore, the significant correlations of Abs 365 with arabitol $(R=0.419-0.494, p<0.01$, Figure 6i), mannitol $(R=0.407-0.422, p<0.01$, Figure 6j), glucose $(R=0.347-0.401, p<0.01$,

425 Figure 6k), trehalose $(R=0.306-0.489, p<0.01$, Figure 61$)$ and xylose $(0.476-0.773, p<0.01$, Figure $6 \mathrm{~m})$ suggest bioaerosols also contributed to $\mathrm{BrC}$ in Tianjin. The potential impacts of bioaerosols on $\mathrm{BrC}$ can be supported by the PARAFAC-derived fluorescent results as discussed in Sect. 3.4.

Moreover, $\mathrm{Abs}_{365}$ and the estimated SOC showed similar variations with strong correlations in both summer $(R=0.693, p<$ $0.01)$ and winter $(R=0.881, p<0.01)$ (Figure $6 \mathrm{~d}$ and S1d), suggesting the significant impacts of secondary formation processes on $\mathrm{BrC}$, even in the winter season. This is reasonable because $\mathrm{SOA}$ are also major contributors to $\mathrm{BrC}$ through photochemical reactions and/or aqueous/heterogeneous chemical processes (Laskin et al., 2014; Lin et al., 2015; Braman et al., 2020; Kasthuriarachchi et al., 2020). The correlation between Abs365 and SOC in winter was even stronger than that between Abs 365 and $\mathrm{EC}$, indicating the greater impacts of secondary formation on winter $\mathrm{BrC}$ compared with the primary emissions from combustion-related activities. The large contribution of secondary formation to wintertime $\mathrm{BrC}$ is also indicated by the strong correlations of $\mathrm{BrC}$ with $\mathrm{SO}_{4}{ }^{2-}$ and $\mathrm{NO}_{3}{ }^{-}$(Figure $6 \mathrm{~g}-\mathrm{h}$ ). To explore the relationships between $\mathrm{BrC}$ and $\mathrm{SOA}$ formed through different reaction pathways, correlations of $\mathrm{Abs}_{365}$ with specific molecular markers of biogenic SOA tracers (e.g., $\mathrm{C}_{5}$-alkene triols, 2-methyltetrols (MTLs), 2-methylglyceric acid (2-MGA), pinic acid, and 3-hydroxyglutaric acid (3-HGA)) and anthropogenic SOA tracers (e.g., 2, 3-dihydroxy-4-oxopentanoic acid (DHOPA), and phthalic acids) were also examined. The ubiquitous biogenic volatile organic compounds (BVOCs) are believed to contribute to the formation of atmospheric $\mathrm{BrC}$ 440 by complex atmospheric processes (Bones et al., 2010; Updyke et al., 2012; Nguyen et al., 2013; Laskin et al., 2015). C5alkene triols and MTLs are the major SOA tracers due to isoprene photooxidation under low-NOx conditions, and 2-MGA is 
a further oxidation product of isoprene under high- $\mathrm{NO}_{\mathrm{x}}$ conditions; Pinic acids is the first-generation oxidation product of monoterpene, while 3-HGA is the higher generation product (Kang et al., 2018; Fan et al., 2020b). Figure 6n-r demonstrates the significant correlations between $\mathrm{Abs}_{365}$ and $\mathrm{C}_{5}$-alkene triols $(R=0.395-0.469, p<0.01)$, MTLs $(R=0.476, p<0.01$ in summer), 2-MGA $(R=0.342-0.514, p<0.01)$, pinic acid $(R=0.231-0.421, p<0.01)$, and 3-HGA $(R=0.388-0.415, p<$ 0.01). These weak to moderate correlation coefficients suggest that the biogenic SOA formation processes are potential sources of $\mathrm{BrC}$ in Tianjin although their contributions might be not large. Since the contributions of biogenic SOA to OC significantly elevated in summer due to the larger emissions of their precursors and strong photooxidation (Fan et al., 2020b), biogenic SOA might be an important source of $\mathrm{BrC}$ in summer. DHOPA and phthalic acids are tracers for the anthropogenic SOA from toluene and naphthalene, respectively (Kleindienst et al., 2012; Fu et al., 2014). Figure 6s-t shows that Abs365 exhibited significantly strong relevancies with DHOPA $(R=0.472-0.638, p<0.01)$ and phthalic acids $(R=0.400-0.742, p<0.01)$, again confirming that anthropogenic SOA formation is also an important source for $\mathrm{BrC}$ in Tianjin. In addition, the much larger correlation coefficients in winter indicate the stronger influence of anthropogenic activities on secondary formation of winter $\mathrm{BrC}$, in accordance with the results suggested by the stronger correlations of winter $\mathrm{BrC}$ with $\mathrm{SO}_{4}{ }^{2-}$ and $\mathrm{NO}_{3}{ }^{-}$.

The potential sources of $\mathrm{BrC}$ in Tianjin with their relative contributions were further analyzed with the PMF model constrained by organic molecular markers. Figure 7 presents the profiles of the five factors, together with the temporal variations in contributions from individual factors. The first factor (F1) is mainly related to anthropogenic SOA formation processes since it is characterized by the highest level of DHOPA. The second factor (F2), which is featured by the high abundances of glucose, trehalose, mannitol and arabitol, is primarily derived from bioaerosol emissions. The third factor (F3), with the largest contributions of levoglucosan and its two isomers (i.e., galactosan and mannosan), is identified as the source of biomass burning, since galactosan and mannosan can also act as biomass burning tracers (Simoneit, 2002). The fourth factor (F4) shows highest loadings of $\mathrm{C}_{5}$-alkene triols, MTLs, 2-MGA, and pinic acid, and therefore, it can be identified as the source from biogenic SOA formation. The fifth factor (F5) had the largest abundances of $\mathrm{SO}_{4}{ }^{2-}, \mathrm{NO}_{3}{ }^{-}, \mathrm{NH}_{4}{ }^{+}, \mathrm{K}^{+}$, and $\mathrm{Cl}^{-}$. Therefore, $\mathrm{F} 5$ is likely to associate with the fossil fuel combustion and aging processes.

Mean relative contributions of various sources to $\mathrm{BrC}$ in Tianjin in different periods are plotted in Figure 8. Obvious diurnal changes were found in source contributions of $\mathrm{BrC}$. Bioaerosol emission made a larger contribution to $\mathrm{BrC}$ at daytime than at nighttime, especially in summer, suggesting the influences of daytime biological activities on $\mathrm{BrC}$ formation. Biomass burning contributed more to $\mathrm{BrC}$ at night, which called for more attentions to nighttime $\mathrm{BrC}$ formation due to biomass-burning activities. In addition to the diurnal differences, remarkable seasonal changes in sources of $\mathrm{BrC}$ also existed. In winter, biomass burning as well as fossil fuel combustion and aging processes were the predominant sources of $\mathrm{BrC}$, with the contributions of $30.7 \%$ and $30.0 \%$, respectively. The predominant contributions of biomass burning and fossil fuel combustion to winter $\mathrm{BrC}$ in Tianjin were coincided with the source apportionment results of $\mathrm{BrC}$ in Xi' an in northwest China (Wu et al., 2020a; Yuan et al, 2020). Anthropogenic SOA formation and bioaerosol emission also made large contributions to $\mathrm{BrC}$ in winter, accounting for $21.1 \%$ and $18.2 \%$, respectively. Biogenic SOA formation made little contribution to winter $\mathrm{BrC}$, which might be due to the weak emissions of BVOCs under low temperature. 
However, in summer, biogenic SOA formation accounting for $23.7 \%$ became a prominent source of BrC. Primary bioaerosol emission (38.1\%) was found to be the most important source of summertime $\mathrm{BrC}$, which was led by the strong biological activities. Anthropogenic SOA formation also played an important role although its relative contribution in summer (19.8\%) was slightly smaller than that in winter, suggesting the considerable significance of anthropogenic secondary BrC in both seasons. Compared to the significant influence in winter, fossil fuel combustion and aging processes in summer played a much minor role in $\mathrm{BrC}$ formation because its relative contribution dramatically decreased to $15.3 \%$. Besides, biomass burning made a trivial contribution of $3.2 \%$ to summer $\mathrm{BrC}$, which contrasted sharply to the dominant contribution in winter. To sum up, the combustion-related primary emissions played a much more important role in $\mathrm{BrC}$ formation in winter, while secondary formation from photochemical and aqueous chemical processes contributed more to $\mathrm{BrC}$ in summer than in winter. Such source apportionment results again indicating that $\mathrm{BrC}$ in Tianjin were more affected by fresh emission and less aged in winter while more aged in summer, in accordance with the fluorescent results. The larger contributions of secondary BrC may also partly explain the lower MAE in summer (Table 1), since atmospheric aging processes would weaken light absorption (Zhong and Jang, 2014; Liu et al., 2016).

\section{Conclusions}

490 This study presents the temporal variations in light absorption and fluorescent properties of water-soluble $\mathrm{BrC}$ in $\mathrm{PM}_{2.5}$ over Tianjin in North China in winter and summer during 2016-2017. Sources of water-soluble BrC were comprehensively analyzed by investigating the relationships of $\mathrm{BrC}$ and chemical compositions of aerosols. Results show that light absorption properties of $\mathrm{BrC}$ experienced obvious seasonal variations. $\mathrm{Abs}_{365}$, $\mathrm{AAE}, \mathrm{MAE}_{365}$, and $k_{365}$ of $\mathrm{BrC}$ were 6.8, 1.1, 1.8, and 1.8 times larger in winter than in summer, respectively, suggesting the much more abundant and stronger light absorbing of watersoluble $\mathrm{BrC}$ in winter. However, there are no significant differences in $\mathrm{BrC}$ light absorption between daytime and nighttime. Water-soluble $\mathrm{BrC}$ contributed significantly to absorption radiative forcing, especially in the UV range, indicating their considerable influences on climate warming and ozone formation. Fluorescent indices present that $\mathrm{BrC}$ were associated with a slightly higher aromaticity degree and polycondensation in their chemical structures in summer and daytime, which was likely resulted from photobleaching processes. Three humic-like components $(\mathrm{C} 1, \mathrm{C} 2$, and $\mathrm{C} 3)$ and two protein-like components (C4 and C5) were determined as the major fluorescent organics by PARAFAC analysis. The humic-like components were predominant in both seasons and their relative contributions were larger in winter than in summer. The lowly-oxygenated humic-like components contributed more in winter and nighttime, while relative contributions of moreoxygenated humic-like components obviously increased in summer and daytime, indicating the less-oxygenated fluorophores might be oxidized into more-oxygenated fluorophores due to photodegradation. Combustion processes and secondary formation remarkably contributed to the humic-like and protein-like fluorescent organic aerosols. Correlation analysis between $\mathrm{BrC}$ and chemical compositions of aerosols as well as source apportionments by PMF analysis with the organic molecular tracers suggested that sources contributions of $\mathrm{BrC}$ presented obvious seasonal and diurnal variations and fossil fuel 
combustion and aging processes, bioaerosol emission, and anthropogenic SOA formation were important sources of $\mathrm{BrC}$ in both winter and summer. Impacts of biomass burning in winter, and primary biological aerosol emission and biogenic secondary formation in summer on $\mathrm{BrC}$ were highlighted by the PMF results. Overall, source contributions and fluorescent properties together indicated that $\mathrm{BrC}$ were prominently affected by freshly emitted aerosols and less aged in winter, while they were more aged in summer. This study broadens our knowledge of optical properties, sources, and evolution formation of $\mathrm{BrC}$ in the heavily polluted urban region in China, which will help to estimate climatic effect of atmospheric aerosols and control carbonaceous aerosol pollution.

Data availability. The data is available upon request from the corresponding author.

Author contribution. PF designed the experiments. JD, XW, SZ, and ZZ carried out the experiments and performed the data analysis. JD prepared the manuscript with contributions from all co-authors.

Competing interests. The authors declare that they have no conflict of interests.

Acknowledgments. This study was supported by the National Key Research and Development Program of China (2019YFA0606801), Strategic Priority Research Program of the Chinese Academy of Sciences (No. XDA23020301), National Natural Science Foundation of China (21607148, 41625014), Natural Science Foundation of Tianjin City (20JCQNJC01590), and Peiyang Young Scholar Program of Tianjin University (2020XRG-0068).

\section{References}

Al-Naiema, I. M., Hettiyadura, A. P. S., Wallace, H. W., Sanchez, N. P., Madler, C. J., Cevik, B. K., Bui, A. A. T., Kettler, J., Griffin, R. J., and Stone, E. A.: Source apportionment of fine particulate matter in Houston, Texas: insights to secondary organic aerosols, Atmos. Chem. Phys., 18, 15601-15622, https://doi.org/10.5194/acp-18-15601-2018, 2018.

Andreae, M. O., and Gelencsér, A.: Black carbon or brown carbon? The nature of light-absorbing carbonaceous aerosols, Atmos. Chem. Phys., 6, 3131-3148, https://doi.org/10.5194/acp-6-3131-2006, 2006.

530 Bahadur, R., Praveen, P., Xu, Y., and Ramanathan, V.: Solar absorption by elemental and brown carbon determined from spectral observations, P. Natl. Acad. Sci. USA., 109, 17366-17371, https://doi.org/10.1073/pnas.1205910109, 2012.

Battin, T. J.: Dissolved organic matter and its optical properties in a blackwater tributary of the upper Orinoco river, Venezuela, Org. Geochem., 28, 561-569, https://doi.org/10.1016/S0146-6380(98)00028-X, 1998.

Bauer, H., Claeys, M., Vermeylen, R., Schueller, E., Weinke, G., Berger, A., and Puxbaum, H.: Arabitol and mannitol as

535 tracers for the quantification of airborne fungal spores, Atmos. Environ., 42, 588-593, https://doi.org/10.1016/j.atmosenv.2007.10.013, 2008.

Baylon, P., Jaffe, D. A., Hall, S. R., Ullmann, K., Alvarado, M. J., and Lefer, B. L.: Impact of biomass burning plumes on photolysis rates and ozone formation at the Mount Bachelor Observatory, J. Geophys. Res. Atmos., 123, 2272-2284, https://doi.org/10.1002/2017JD027341, 2018. 
540 Birdwell, J. E., and Engel, A. S.: Characterization of dissolved organic matter in cave and spring waters using UV-Vis absorbance and fluorescence spectroscopy, Org. Geochem., 41, 270-280, https://doi.org/10.1016/j.orggeochem.2009.11.002, 2010.

Bond, T. C., and Bergstrom, R. W.: Light absorption by carbonaceous particles: An investigative review, Aerosol Sci. Tech., 40, 27-67, https://doi.org/10.1080/02786820500421521, 2006.

545 Bones, D. L., Henricksen, D. K., Mang, S. A., Gonsior, M., Bateman, A. P., Nguyen, T. B., Cooper, W. J., and Nizkorodov, S. A.: Appearance of strong absorbers and fluorophores in limonene- $\mathrm{O}_{3}$ secondary organic aerosol due to $\mathrm{NH}_{4}{ }^{+}$-mediated chemical aging over long time scales, J. Geophys. Res., 115, D05203, https://doi.org/10.1029/2009JD012864, 2010.

Bosch, C., Andersson, A., Kirillova, E. N., Budhavant, K., Tiwari, S., Praveen, P. S., Russell, L. M., Beres, N. D., Ramanathan, V., and Gustafsson, Ö.: Source-diagnostic dual-isotope composition and optical properties of water-soluble organic carbon

550 and elemental carbon in the South Asian outflow intercepted over the Indian Ocean, J. Geophys. Res. Atmos., 119, 1174311759, https://doi:10.1002/2014JD022127, 2014.

Braman, T., Dolvin, L., Thrasher, C., Yu, H., Walhout, E. Q., and O’Brien, R. E.: Fresh versus Photo-recalcitrant Secondary Organic Aerosol: Effects of Organic Mixtures on Aqueous Photodegradation of 4-Nitrophenol, Environ. Sci. Technol. Lett., 7, 248-253, https://doi.org/10.1021/acs.estlett.0c00177, 2020.

555 Castro, L. M., Pio, C. A., Harrison, R. M., and Smith, D. J. T.: Carbonaceous aerosol in urban and rural European atmospheres: estimation of secondary organic carbon concentrations, Atmos. Environ., 33, 2771-2781. https://doi.org/10.1016/S13522310(98)00331-8, 1999.

Chakrabarty, R. K., Moosmüller, H., Chen, L.-W. A., Lewis, K., Arnott, W. P., Mazzoleni, C., Dubey, M. K., Wold, C. E., Hao, W. M., and Kreidenweis, S. M.: Brown carbon in tar balls from smoldering biomass combustion, Atmos. Chem. Phys., 560 10, 6363-6370, https://doi.org/10.5194/acp-10-6363-2010, 2010.

Chen, Q., Miyazaki, Y., Kawamura, K., Matsumoto, K., Coburn, S., Volkamer, R., Iwamoto, Y., Kagami, S., Deng, Y., Ogawa, S., Ramasamy, S., Kato, S., Ida, A., Kajii, Y., and Mochida, M.: Characterization of chromophoric water-soluble organic matter in urban, forest, and marine aerosols by HR-ToF-AMS analysis and excitation-emission matrix spectroscopy, Environ. Sci. Technol., 50, 10351-10360, https://doi.org/10.1021/acs.est.6b01643, 2016.

565 Chen, Q., Li, J., Hua, X., Jiang, X., Mu, Z., Wang, M., Wang, J., Shan, M., Yang, X., Fan, X., Song, J., Wang, Y., Guan, D., and Du, L.: Identification of species and sources of atmospheric chromophores by fluorescence excitation-emission matrix with parallel factor analysis, Sci. Total Environ., 718, 137322, https://doi.org/10.1016/j.scitotenv.2020.137322, 2020.

Chen, Y., and Bond, T. C.: Light absorption by organic carbon from wood combustion, Atmos. Chem. Phys., 10, 1773-1787, https://doi.org/10.5194/acp-10-1773-2010, 2010.

570 Cheng, Y., He, K.-B., Zheng, M., Duan, F. K., Du, Z.-Y., Ma, Y.-L., Tan, J. H., Yang, F. M., Liu, J. M., Zhang, X. L., Weber, R. J., Bergin, M. H., and Russell, A. G.: Mass absorption efficiency of elemental carbon and water-soluble organic carbon in Beijing, China, Atmos. Chem. Phys., 11, 11497-11510, https://doi.org/10.5194/acp-11-11497-2011, 2011. 
Choudhary, V., Rajput, P., and Gupta, T.: Absorption properties and forcing efficiency of light-absorbing water-soluble organic aerosols: Seasonal and spatial variability, Environ. Pollut., 272, 115932, https://doi.org/10.1016/j.envpol.2020.115932, 2021.

Coble, P. G.: Characterization of marine and terrestrial DOM in seawater using excitation-emission matrix spectroscopy, Mar. Chem., 51, 4, 325-346, https://doi.org/10.1016/0304-4203(95)00062-3, 1996.

Coble, P. G.: Marine optical biogeochemistry: the chemistry of ocean color, Chem. Rev., 107, 402-418, https://doi.org/10.1021/cr050350+, 2007.

Dasari, S., Andersson, A., Bikkina, S., Holmstrand, H., Budhavant, K., Satheesh, S., Asmi, E., Kesti, J., Backman, J., Salam, A., Bisht, D. S., Tiwari, S., Hameed, Z., and Gustafsson, Ö.: Photochemical degradation affects the light absorption of watersoluble brown carbon in the South Asian outflow, Sci. Adv., 5, eaau8066, https://doi.org/10.1126/sciadv.aau8066, 2019.

Desyaterik, Y., Y. Sun, X. Shen, T. Lee, X. Wang, T. Wang, and J. L. Collett Jr.: Speciation of "brown" carbon in cloud water impacted by agricultural biomass burning in eastern China, J. Geophys. Res. Atmos., 118, 7389-7399, http://doi.org/10.1002/jgrd.50561, 2013.

Dey, S., Mukherjee, A., Polana, A. J., Rana, A., Mao, J., Jia, S., Yadav, A. K., Khillare, P. S., and Sarkar, S.: Brown carbon aerosols in the Indo-Gangetic Plain outflow: insights from excitation emission matrix (EEM) fluorescence spectroscopy, Environ. Sci.: Processes Impact, 23, 745, http://doi.org/10.1039/d1em00050k, 2021.

Du, Z., He, K., Cheng, Y., Duan, F., Ma, Y., Liu, J., Zhang, X., Zheng, M., and Weber, R.: A yearlong study of water-soluble organic carbon in Beijing II: Light absorption properties, Atmos. Environ., 89, 235-241, https://doi.org/10.1016/j.atmosenv.2014.02.022, 2014.

Elcoroaristizabal, S., de Juan, A., Garcia, J. A., Elorduy, I., Durana, N., and Alonso, L.: Chemometric determination of PAHs in aerosol samples by fluorescence spectroscopy and second-order data analysis algorithms, J. Chemometrics, 28, 260-271, https://doi.org/10.1002/cem.2604, 2014.

595 Fan, X., Cao, T., Yu, X., Wang, Y., Xiao, X., Li, F., Xie, Y., Ji, W., Song, J., and Peng, P.: The evolutionary behavior of chromophoric brown carbon during ozone aging of fine particles from biomass burning, Atmos. Chem. Phys., 20, 4593-4605, https://doi.org/10.5194/acp-20-4593-2020, 2020a.

Fan, Y., Liu, C.-Q., Li, L., Ren, L., Ren, H., Zhang, Z., Li, Q., Wang, S., Hu, W., Deng, J., Wu, L., Zhong, S., Zhao, Y., Pavuluri, C. M., Li, X., Pan, X., Sun, Y., Wang, Z., Kawamura, K., Shi, Z., and Fu, P.: Large contributions of biogenic and anthropogenic 600 sources to fine organic aerosols in Tianjin, North China, Atmos. Chem. Phys., 20, 117-137, https://doi.org/10.5194/acp-20117-2020, 2020b.

Feng, Y., Ramanathan, V., and Kotamarthi, V. R.: Brown carbon: a significant atmospheric absorber of solar radiation? Atmos. Chem. Phys., 13, 8607-8621, https://doi.org/10.5194/acp-13-8607-2013, 2013.

Forrister, H., Liu, J., Scheuer, E., Dibb, J., Ziemba, L., Thornhill, K. L., Anderson, B., Diskin, G., Perring, A. E., Schwarz, J.

605 P., Campuzano-Jost, P., Day, D. A., Palm, B. B., Jimenez, J. L., Nenes, A., and Weber, R. J.: Evolution of brown carbon in wildfire plumes, Geophys. Res. Lett., 42, 4623-4630, https://doi.org/10.1002/2015g1063897, 2015. 
Fu P, Kawamura K, Chen J, and Miyazaki, Y.: Secondary production of organic aerosols from biogenic VOCs over Mt. Fuji, Japan, Environ. Sci. Technol., 48, 15, 8491-8497, http://doi.org/10.1021/es500794d, 2014.

Fu, P., Kawamura, K., Chen, J., Qin, M., Ren, L., Sun, Y., Wang, Z., Barrie, L. A., Tachibana, E., Ding, A., and Yamashita,

610 Y.: Fluorescent water-soluble organic aerosols in the High Arctic atmosphere, Sci. Rep., 5, 9845, https://doi.org/10.1038/srep09845, 2015.

Gao, J., Wang, K., Wang, Y., Liu, S., Zhu, C., Hao, J., Liu, H., Hua, S., and Tian, H.: Temporal-spatial characteristics and source apportionment of $\mathrm{PM}_{2.5}$ as well as its associated chemical species in the Beijing-Tianjin-Hebei region of China, Environ. Pollut., 233, 714-724, https://doi.org/10.1016/j.envpol.2017.10.123, 2018.

615 Ge, B., Wang, Z., Lin, W., Xu, X., Li, J., Ji, D., and Ma, Z.: Air pollution over the North China Plain and its implication of regional transport: A new sight from the observed evidences, Environ. Pollut., 234, 29-38, https://doi.org/10.1016/j.envpol.2017.10.084, 2018.

Guo, S., Hu, M., Zamora, M. L., Peng, J., Shang, D., Zheng, J., Du, Z., Wu, Z., Shao, M., Zeng, L., Molina, M. J., and Zhang, R.: Elucidating severe urban haze formation in China, , P. Natl. Acad. Sci. USA, 111, 17373-17378, https://doi.org/10.1073/pnas.1419604111, 2014.

He, Q., Tomaz, S., Li, C., Zhu, M., Meidan, D., Riva, M., Laskin, A., Brown, S. S., George, C., Wang, X., and Rudich, Y.: Optical Properties of Secondary Organic Aerosol Produced by Nitrate Radical Oxidation of Biogenic Volatile Organic Compounds, Environ. Sci. Technol., 55, 2878-2889, https://doi.org/10.1021/acs.est.0c06838, 2021.

Hecobian, A., Zhang, X., Zheng, M., Frank, N., Edgerton, E. S., and Weber, R. J.: Water-Soluble Organic Aerosol material and the light-absorption characteristics of aqueous extracts measured over the Southeastern United States, Atmos. Chem. Phys., 10, 5965-5977, https://doi.org/10.5194/acp-10-5965-2010, 2010.

Hettiyadura, A. P. S., Garcia, V., Li, C., West, C. P., Tomlin, J., He, Q., Rudich, Y., and Laskin, A.: Chemical Composition and Molecular-Specific Optical Properties of Atmospheric Brown Carbon Associated with Biomass Burning, Environ. Sci. Technol., 55, 4, 2511-2521, https://doi.org/10.1021/acs.est.0c05883, 2021.

Hu, W., Wang, Z., Huang, S., Ren, L., Yue, S., Li, P., Xie, Q., Zhao, W., Wei, L., Ren, H., Wu, L., Deng, J., Fu, P.: Biological Aerosol Particles in Polluted Regions, Curr. Pollut. Rep., 6, 2, 65-89, https://doi.org/10.1007/s40726-020-00138-4, 2020. Huang, R. J., Yang, L., Cao, J., Chen, Y., Chen, Q., Li, Y., Duan, J., Zhu, C., Dai, W., Wang, K., Lin, C., Ni, H., Corbin, J. C., Wu, Y., Zhang, R., Tie, X., Hoffmann, T., O’Dowd, C., and Dusek, U.: Brown carbon aerosol in urban Xi' an, Northwest China: the composition and light absorption properties, Environ. Sci. Technol., 52, 6825-6833, https://doi.org/10.1021/acs.est.8b02386, 2018.

Huang, X., Liu, Z., Liu, J., Hu, B., Wen, T., Tang, G., Zhang, J., Wu, F., Ji, D., Wang, L., and Wang, Y.: Chemical characterization and source identification of $\mathrm{PM}_{2.5}$ at multiple sites in the Beijing-Tianjin-Hebei region, China, Atmos. Chem. Phys., 17, 12941-12962, https://doi.org/10.5194/acp-17-12941-2017, 2017.

Huguet, A., Vacher, L., Relexans, S., Saubusse, S., Froidefond, J. M., and Parlanti, E.: Properties of fluorescent dissolved organic matter in the Gironde Estuary, Org. Geochem., 40, 706-719, https://doi.org/10.1016/j.orggeochem.2009.03.002, 2009. 
Jo, D. S., Park, R. J., Lee, S., Kim, S.-W., and Zhang, X.: A global simulation of brown carbon: implications for photochemistry and direct radiative effect, Atmos. Chem. Phys., 16, 3413-3432, https://doi.org/10.5194/acp-16-3413-2016, 2016.

Kang, M., Fu, P., Kawamura, K., Yang, F., Zhang, H., Zang, Z., Ren, H., Ren, L., Zhao, Y., Sun, Y., and Wang, Z.: Characterization of biogenic primary and secondary organic aerosols in the marine atmosphere over the East China Sea, Atmos. Chem. Phys., 18, 13947-13967, https://doi.org/10.5194/acp-18-13947-2018, 2018.

Kasthuriarachchi, N. Y., Rivellini, L. -H., Chen, X., Li, Y. J., and Lee, A. K. Y.: Effect of Relative Humidity on Secondary Brown Carbon Formation in Aqueous Droplets, Environ. Sci. Technol., 54, 13207-13216, https://doi.org/10.1021/acs.est.0c01239, 2020.

Kirillova, E. N., Andersson, A., Tiwari, S., Srivastava, A. K., Bisht, D. S., and Gustafsson, Ö.: Water-soluble organic carbon aerosols during a full New Delhi winter: Isotope-based source apportionment and optical properties, J. Geophys. Res. Atmos., 119, 3476-3485, https://doi.org/10.1002/2013JD020041, 2014.

Kirillova, E. N., Marinoni, A., Bonasoni, P., Vuillermoz, E., Facchini, M. C., Fuzzi, S., and Decesari, S.: Light absorption properties of brown carbon in the high Himalayas, J. Geophys. Res. Atmos., 121, 9621-9639, http://doi.org/10.1002/2016JD025030, 2016.

655 Kleindienst, T. E., Jaoui, M., Lewandowski, M., Offenberg, J. H., and Docherty, K. S.: The formation of SOA and chemical tracer compounds from the photooxidation of naphthalene and its methyl analogs in the presence and absence of nitrogen oxides, Atmos. Chem. Phys., 12, 8711-8726, https://doi.org/10.5194/acp-12-8711-2012, 2012.

Lack, D. A., Langridge, J. M., Bahreini, R., Cappa, C. D., Middlebrook, A. M., and Schwarz, J. P.: Brown carbon and internal mixing in biomass burning particles, P. Natl. Acad. Sci. USA, 109, 14802-14807, https://doi.org/10.1073/pnas.1206575109, 2012.

Laskin, A., Laskin, J., and Nizkorodov, S. A.: Chemistry of Atmospheric Brown Carbon, Chem. Rev., 115, 10, 4335-4382, https://doi.org/10.1021/cr5006167, 2015.

Laskin, J., Laskin, A., Nizkorodov, S. A., Roach, P., Eckert, P., Gilles, M. K., Wang, B., Lee, H. J., and Hu, Q.: Molecular selectivity of brown carbon chromophores, Environ. Sci. Technol., 48, 12047-12055, https://doi.org/10.1021/es503432r, 2014. Lee, H. J., Aiona, P. K., Laskin, A., Laskin, J., and Nizkorodov, S. A.: Effect of Solar Radiation on the Optical Properties and Molecular Composition of Laboratory Proxies of Atmospheric Brown Carbon, Environ. Sci. Technol., 48, 10217. https://doi.org/10.1021/es502515r, 2014.

Lee, H. J., Laskin, A., Laskin, J., and Nizkorodov, S. A.: Excitation-Emission Spectra and Fluorescence Quantum Yields for Fresh and Aged Biogenic Secondary Organic Aerosols, Environ. Sci. Technol., 47, 5763-5770, https://doi.org/10.1021/es400644c, 2013.

Lei, Y., Shen, Z., Zhang, T., Zhang, Q., Wang, Q., Sun, J., Gong, X., Cao, J., Xu, H., and Liu, S.: Optical source profiles of brown carbon in size-resolved particulate matter from typical domestic biofuel burning over Guanzhong Plain, China, Sci. Total Environ., 622, 244-251, https://doi.org/10.1016/j.scitotenv.2017.11.353, 2018.

Levinson, R., Akbari, H., and Berdahl, P.: Measuring solar reflectance—Part I: Defining a metric that accurately predicts solar 
heat gain, Sol. Energy, 84, 1717-1744, https://doi.org/10.1016/j.solener.2010.04.018, 2010.

Li, C., He, Q., Hettiyadura, A. P. S., Käfer, U., Shmul, G., Meidan, D., Zimmermann, R., Brown, S. S., George, C., Laskin, A., and Rudich, Y.: Formation of Secondary Brown Carbon in Biomass Burning Aerosol Proxies through $\mathrm{NO}_{3} \mathrm{Radical}$ Reactions, Environ. Sci. Technol., 54, 1395-1405, https://doi.org/10.1021/acs.est.9b05641, 2020a.

Li, J., Chen, Q., Hua, X., Chang, T., and Wang, Y.: Occurrence and sources of chromophoric organic carbon in fine particulate matter over Xi'an, China, Sci. Total Environ., 725, 138290, https://doi.org/10.1016/j.scitotenv.2020.138290, 2020 b.

Li, J., Zhang, Q., Wang, G., Li, J., Wu, C., Liu, L., Wang, J., Jiang, W., Li, L., Ho, K. F., and Cao, J.: Optical properties and molecular compositions of water-soluble and water-insoluble brown carbon $(\mathrm{BrC})$ aerosols in northwest China, Atmos. Chem. Phys., 20, 4889-4904, https://doi.org/10.5194/acp-20-4889-2020, 2020c.

Li, K., Jacob, D. J., Liao, H., Qiu, Y., Shen, L., Zhai, S., Bates, K. H., Sulprizio, M. P., Song, S., Lu, X., Zhang, Q., Zheng, B.,

685 Zhang, Y., Zhang, J., Lee, H. C., and Kuk, S. K.: Ozone pollution in the North China Plain spreading into the late-winter haze season, P. Natl. Acad. Sci. USA., 118, e2015797118, https://doi.org/10.1073/pnas.2015797118, 2021.

Li, M., Fan, X., Zhu, M., Zou, C., Song, J., Wei, S., Jia, W., and Peng, P.: Abundance and Light Absorption Properties of Brown Carbon Emitted from Residential Coal Combustion in China, Environ. Sci. Technol., 53, 595-603, https://doi.org/10.1021/acs.est.8b05630, 2019.

690 Li, R., Wang, Q., He, X., Zhu, S., Zhang, K., Duan, Y., Fu, Q., Qiao, L., Wang, Y., Huang, L., Li, L., and Yu, J. Z.: Source apportionment of PM2.5 in Shanghai based on hourly organic molecular markers and other source tracers, Atmos. Chem. Phys., 20, 12047-12061, https://doi.org/10.5194/acp-20-12047-2020, 2020d.

Li, X., Yang, Y., Liu, S., Zhao, Q., Wang, G., and Wang, Y.: Light absorption properties of brown carbon (BrC) in autumn and winter in Beijing: Composition, formation and contribution of nitrated aromatic compounds, Atmos Environ., 223, 117289,

695 https://doi.org/10.1016/j.atmosenv.2020.117289, 2020e.

Lin, P., Aiona, P. K., Li, Y., Shiraiwa, M., Laskin, J., Nizkorodov, S. A., and Laskin, A.: Molecular Characterization of Brown Carbon in Biomass Burning Aerosol Particles, Environ. Sci. Technol., 50, 11815-11824, https://doi.org/10.1021/acs.est.6b03024, 2016.

Lin, P., Bluvshtein, N., Rudich, Y., Nizkorodov, S. A., Laskin, J., and Laskin, A.: Molecular Chemistry of Atmospheric Brown

700 Carbon Inferred from a Nationwide Biomass Burning Event, Environ. Sci. Technol., 51, 11561-11570, http://doi.org/10.1021/acs.est.7b02276, 2017.

Lin, P., Liu, J., Shilling, J. E., Kathmann, S. M., Laskin, J., and Laskin, A.: Molecular characterization of brown carbon (BrC) chromophores in secondary organic aerosol generated from photo-oxidation of toluene, Phys. Chem. Chem. Phys., 17, 2331223325, https://doi.org/10.1039/c5cp02563j, 2015.

705 Liu, J., Bergin, M., Guo, H., King, L., Kotra, N., Edgerton, E., and Weber, R. J.: Size-resolved measurements of brown carbon in water and methanol extracts and estimates of their contribution to ambient fine-particle light absorption, Atmos. Chem. Phys., 13, 12389-12404, https://doi.org/10.5194/acp-13-12389-2013, 2013.

Liu, J., Lin, P., Laskin, A., Laskin, J., Kathmann, S. M., Wise, M., Caylor, R., Imholt, F., Selimovic, V., and Shilling, J. E.: 
Optical properties and aging of light-absorbing secondary organic aerosol, Atmos. Chem. Phys., 16, 12815-12827, https://doi.org/10.5194/acp-16-12815-2016, 2016.

Matos, J. T. V., Freire, S. M. S. C., Duarte, R. M. B. O., and Duarte, A. C.: Natural organic matter in urban aerosols: Comparison between water and alkaline soluble components using excitation-emission matrix fluorescence spectroscopy and multiway data analysis, Atmos. Environ., 102, 1-10, http://doi.org/10.1016/j.atmosenv.2014.11.042, 2015.

McKnight, D. M., Boyer, E. W., Westerhoff, P. K., Doran, P. T., Kulbe, T., and Andersen, D. T.: Spectrofluorometric characterization of dissolved organic matter for indication of precursor organic material and aromaticity, Limnol. Oceanogr., 46 (1), 38-48, https://doi.org/10.4319/lo.2001.46.1.0038, 2001.

Mladenov, N., Alados-Arboledas, L., Olmo, F.J., Lyamani, H., Delgado, A., Molina, A., and Reche, I.: Applications of optical spectroscopy and stable isotope analyses to organic aerosol source discrimination in an urban area, Atmos. Environ., 45, 1960-1969, http://doi.org/10.1016/j.atmosenv.2011.01.029, 2011.

Moise, T., Flores, J. M., and Rudich, Y.: Optical properties of secondary organic aerosols and their changes by chemical processes, Chem. Rev., 115, 4 400-4439, https://doi.org/10.1021/cr5005259, 2015.

Mok, J., Krotkov, N., Arola, A. Torres, O., Jethva, H., Andrade, M., Labow, G., Eck, T. F., Li, Z., Dickerson, R. R., Stenchikov, G. L., Osipov, S., and Ren, X.: Impacts of brown carbon from biomass burning on surface UV and ozone photochemistry in the Amazon Basin, Sci. Rep., 6, 36940, https://doi.org/10.1038/srep36940, 2016.

Moschos, V., Kumar, N. K., Daellenbach, K. R., Baltensperger, U., Prévôt, A. S. H., and El Haddad, I.: Source Apportionment of Brown Carbon Absorption by Coupling Ultraviolet-Visible Spectroscopy with Aerosol Mass Spectrometry, Environ. Sci. Tech. Let., 5, 302-308, https://doi.org/10.1021/acs.estlett.8b00118, 2018.

Murphy, K. R., Hambly, A., Singh, S., Henderson, R. K., Baker, A., Stuetz, R., and Khan, S. J.: Organic Matter Fluorescence in Municipal Water Recycling Schemes: Toward a Unified PARAFAC Model, Environ. Sci. Technol., 45, 2909-2916, http://doi.org/10.1021/es103015e, 2011.

Murphy, K. R., Stedmon, C. A., Graeber, D., and Bro, R.: Fluorescence spectroscopy and multi-way techniques. PARAFAC, Anal. Methods, 5, 6557-6566, https://doi.org/10.1039/C3AY41160E, 2013.

Nguyen, T. B., Laskin, A., Laskin, J., and Nizkorodov, S. A.: Brown carbon formation from ketoaldehydes of biogenic monoterpenes, Faraday Discuss., 165, 473-494, https://doi.org/10.1039/C3FD00036B, 2013.

735 Ni, H., Huang, R. J., Pieber, S. M., Corbin, J. C., Stefenelli, G., Pospisilova, V., Klein, F., Gysel-Beer, M., Yang, L., Baltensperger, U., Haddad, I. E., Slowik, J. G., Cao, J., Prévôt, A. S. H., and Dusek, U.: Brown Carbon in Primary and Aged Coal Combustion Emission, Environ. Sci. Technol., 55, 5701-5710, http://doi.org/10.1021/acs.est.0c08084, 2021.

Paatero, P. and Tapper, U.: Positive matrix factorization: A nonnegative factor model with optimal utilization of error estimates of data values, Environmetrics, 5, 111-126, 1994.

740 Pacini, E.: From anther and pollen ripening to pollen presentation, Plant Syst. Evol., 222, 19-43, https://doi.org/10.1007/BF00984094, 2000.

Palm, B. B., Peng, Q., Fredrickson, C. D., Lee, B. H., Garofalo, L. A., Pothier, M. A., Kreidenweis, S. M., Farmer, D. K., 
Pokhrel, R. P., Shen, Y., Murphy, S. M., Permar, W., Hu, L., Campos, T. L., Hall, S. R., Ullmann, K., Zhang, X., Flocke, F., Fischer, E. V., and Thornton, J. A.: Quantification of organic aerosol and brown carbon evolution in fresh wildfire plumes, P. Natl. Acad. Sci. USA, 117, 29469-29477, https://doi.org/10.1073/pnas.2012218117, 2020.

Pöhlker, C., Huffman, J. A., and Pöschl, U.: Autofluorescence of atmospheric bioaerosols - fluorescent biomolecules and potential interferences, Atmos. Meas. Tech., 5, 37-71, https://doi.org/10.5194/amt-5-37-2012, 2012.

Pöhlker, C., Huffman, J. A., Förster, J.-D., and Pöschl, U.: Autofluorescence of atmospheric bioaerosols: spectral fingerprints and taxonomic trends of pollen, Atmos. Meas. Tech., 6, 3369-3392, https://doi.org/10.5194/amt-6-3369-2013, 2013.

Qin, J., Zhang, L., Zhou, X., Duan, J., Mu, S., Xiao, K., Hu, J., and Tan, J.: Fluorescence fingerprinting properties for exploring water-soluble organic compounds in $\mathrm{PM}_{2.5}$ in an industrial city of northwest China, Atmos. Environ., 184, 203-211, https://doi.org/10.1016/j.atmosenv.2018.04.049, 2018.

Shamjad, P. M., Tripathi, S. N., Thamban, N. M., and Vreeland, H.: Refractive index and absorption attribution of highly absorbing brown carbon aerosols from an urban Indian city-Kanpur, Sci. Rep., 6 (1), 37735, https://doi.org/10.1038/srep37735, 2016.

Shamjad, P. M., Satish, R. V., Thamban, N. M., Rastogi, N., and Tripathi, S. N.: Absorbing Refractive Index and Direct Radiative Forcing of Atmospheric Brown Carbon over Gangetic Plain, ACS Earth Space Chem., 2, 31-37. https://doi.org/10.1021/acsearthspacechem.7b00074, 2018.

Simoneit, B. R. T.: Biomass burning - a review of organic tracers for smoke from incomplete combustion, Appl. Geochem.,

17, 129-162, https://doi.org/10.1016/S0883-2927(01)00061-0, 2002.

Simoneit, B. R. T., Elias, V. O., Kobayashi, M., Kawamura, K., Rushdi, A. I., Medeiros, P. M., Rogge, W. F., and Didyk, B. M.: Sugars - Dominant water-soluble organic compounds in soils and characterization as tracers in atmospheric particulate matter, Environ. Sci. Technol., 38, 5939-5949, https://doi.org/10.1021/es0403099, 2004.

Stedmon, C. A., and Markager, S.: Resolving the variability in dissolved organic matter fluorescence in a temperate estuary and its catchment using PARAFAC analysis, Limnol. Oceanogr., 50, 686-697, https://10.4319/lo.2005.50.2.0686, 2005.

Sumlin, B. J., Pandey, A., Walker, M. J., Pattison, R. S., Williams, B. J., and Chakrabarty, R. K.: Atmospheric photooxidation diminishes light absorption by primary brown carbon aerosol from biomass burning, Environ. Sci. Technol. Lett., 4, 540-545, https://doi.org/10.1021/acs.estlett.7b00393, 2017.

Sun, J., Zhi, G., Hitzenberger, R., Chen, Y., Tian, C., Zhang, Y., Feng, Y., Cheng, M., Zhang, Y., Cai, J., Chen, F., Qiu, Y., Jiang, Z., Li, J., Zhang, G., and Mo, Y.: Emission factors and light absorption properties of brown carbon from household coal combustion in China, Atmos. Chem. Phys., 17, 4769-4780, https://doi.org/10.5194/acp-17-4769-2017, 2017.

Tang, J., Li, J., Su, T., Han, Y., Mo, Y., Jiang, H., Cui, M., Jiang, B., Chen, Y., Tang, J., Song, J., Peng, P., and Zhang, G.: Molecular compositions and optical properties of dissolved brown carbon in biomass burning, coal combustion, and vehicle emission aerosols illuminated by excitation-emission matrix spectroscopy and Fourier transform ion cyclotron resonance mass spectrometry analysis, Atmos. Chem. Phys., 20, 2513-2532, https://doi.org/10.5194/acp-20-2513-2020, 2020.

Tang, J., Wang, J., Zhong, G., Jiang, H., Mo, Y., Zhang, B., Geng, X., Chen, Y., Tang, J., Tian, C., Bualert, S., Li, J., and Zhang, 
G.: Measurement report: Long-emission-wavelength chromophores dominate the light absorption of brown carbon in aerosols over Bangkok: impact from biomass burning, Atmos. Chem. Phys., 21, 11337-11352, https://doi.org/10.5194/acp-21-11337$2021,2021$.

Updyke, K. M., Nguyen, T. B., and Nizkorodov, S. A.: Formation of brown carbon via reactions of ammonia with secondary organic aerosols from biogenic and anthropogenic precursors, Atmos. Environ., 63, 22-31, https://doi.org/10.1016/j.atmosenv.2012.09.012, 2012.

Wan, X., Kang, S., Rupakheti, M., Zhang, Q., Tripathee, L., Guo, J., Chen, P., Rupakheti, D., Panday, A. K., Lawrence, M. G., Kawamura, K., and Cong, Z.: Molecular characterization of organic aerosols in the Kathmandu Valley, Nepal: insights into primary and secondary sources, Atmos. Chem. Phys., 19, 2725-2747, https://doi.org/10.5194/acp-19-2725-2019, 2019.

Wang, H., Zhang, L., Huo, T., Wang, B., Yang, F., Chen, Y., Tian, M., Qiao, B., and Peng, C.: Application of parallel factor analysis model to decompose excitation-emission matrix fluorescence spectra for characterizing sources of water-soluble brown carbon in PM2.5, Atmos. Environ., 223, 117192, https://doi.org/10.1016/j.atmosenv.2019.117192, 2020.

Wang, Q. Q., He, X., Huang, X. H. H., Griffith, S. M., Feng, Y. M., Zhang, T., Zhang, Q. Y., Wu, D., and Yu, J. Z.: Impact of secondary organic aerosol tracers on tracer-based source apportionment of organic carbon and $\mathrm{PM}_{2.5}$ : A case study in the Pearl River Delta, China, ACS Earth Space Chem., 1, 562-571, https://doi.org/10.1021/acsearthspacechem.7b00088, 2017.

Wong, J. P. S., Nenes, A., and Weber, R. J.: Changes in light absorptivity of molecular weight separated brown carbon due to photolytic aging, Environ. Sci. Technol., 51, 8414-8421, https://doi.org/10.1021/acs.est.7b01739, 2017.

Wu, C., Wang, G., Li, J., Li, J., Cao, C., Ge, S., Xie, Y., Chen, J., Li, X., Xue, G., Wang, X., Zhao, Z., and Cao, F.: The characteristics of atmospheric brown carbon in Xi'an, inland China: sources, size distributions and optical properties, Atmos. Chem. Phys., 20, 2017-2030, https://doi.org/10.5194/acp-20-2017-2020, 2020a.

Wu, G., Fu, P., Ram, K., Song, J., Chen, Q., Kawamura, K., Wan, X., Kang, S., Wang, X., Laskin, A., and Cong, Z.: Fluorescence characteristics of water-soluble organic carbon in atmospheric aerosol, Environ. Pollut., 268, 115906, https://doi.org/10.1016/j.envpol.2020.115906, 2021.

800 Wu, G., Wan, X., Ram, K., Li, P., Liu, B., Yin, Y., Fu, P., Loewen, M., Gao, S., Kang, S., Kawamura, K., Wang, Y., and Cong, Z.: 2020.: Light absorption, fluorescence properties and sources of brown carbon aerosols in the Southeast Tibetan Plateau, Environ. Pollut., 257, 113616, https://doi.org/10.1016/j.envpol.2019.113616, $2020 \mathrm{~b}$.

Wu, G., Wan, X., Ram, K., Li, P., Yin, Y., Fu, P., Loewen, M., Gao, S., Kang, S., Kawamura, K., Wang, Y., and Cong, Z.: Light absorption, fluorescence properties and sources of brown carbon aerosols in the Southeast Tibetan Plateau, Environ. Sci.

805 Technol., 53, 3471-3479, http://doi.org/10.1021/acs.est.9b00596, 2019.

Xie, M. J., Chen, X., Holder, A. L., Hays, M. D., Lewandowski, M., Offenberg, J. H., Kleindienst, T. E., Jaoui, M., and Hannigan, M. P.: Light absorption of organic carbon and its sources at a southeastern U.S. location in summer, Environ. Pollut., 244, 38-46, https://doi.org/10.1016/j.envpol.2018.09.125, 2019.

Xie, M., Mladenov, N., Williams, M. W., Neff, J. C., Wasswa, J., and Hannigan1, M. P.: Water soluble organic aerosols in the 810 Colorado Rocky Mountains, USA: composition, sources and optical properties, Sci. Rep., 6, 39339, 
https://doi.org/10.1038/srep39339, 2016.

Xie, M., Wang, G., Hu, S., Han, Q., Xu, Y., and Gao, Z.: Aliphatic alkanes and polycyclic aromatic hydrocarbons in atmospheric $\mathrm{PM}_{10}$ aerosols from Baoji, China: Implications for coal burning, Atmos. Res., 93, 840-848, https://doi.org/10.1016/j.atmosres.2009.04.004, 2009.

815 Xie, X., Chen, Y., Nie, D., Liu, Y., Liu, Y., Lei, R., Zhao, X., Li, H., and Ge, X.: Light-absorbing and fluorescent properties of atmospheric brown carbon: A case study in Nanjing, China, Chemosphere, 251, 126350, https://doi.org/10.1016/j.chemosphere.2020.126350, 2020.

Yan, C., Zheng, M., Desyaterik, Y., Sullivan, A. P., Wu, Y., and Collett, J. L. Jr.: Molecular characterization of water-soluble brown carbon chromophores in Beijing, China, J. Geophys. Res.: Atmos., 125, e2019JD032018, 820 https://doi.org/10.1029/2019JD032018, 2020.

Yan, J., Wang, X., Gong, P., Wang, C., and Cong, Z.: Review of brown carbon aerosols: Recent progress and perspectives, Sci. Total Environ., 634, 1475-1485, https://doi.org/10.1016/j.scitotenv.2018.04.083, 2018.

Yu, H., Liang, H., Qu, F., Han, Z., Shao, S., Chang, H., and Li, G.: Impact of data diversity on accuracy and sensitivity of parallel factor analysis model of dissolved organic matter fluorescence excitation-emission matrix, Sci. Rep., 5, 10207, http://doi.org/10.1038/srep10207, 2015.

Yuan, W., Huang, R.-J., Yang, L., Guo, J., Chen, Z., Duan, J., Wang, T., Ni, H., Han, Y., Li, Y., Chen, Q., Chen, Y., Hoffmann, T., and O'Dowd, C.: Characterization of the light-absorbing properties, chromophore composition and sources of brown carbon aerosol in Xi'an, northwestern China, Atmos. Chem. Phys., 20, 5129-5144, https://doi.org/10.5194/acp-20-5129-2020, 2020. Yue, S., Bikkina, S., Gao, M., Barrie, L. A., Kawamura, K., and Fu, P.: Sources and radiative absorption of water-soluble brown carbon in the high Arctic atmosphere, Geophys. Res. Lett., 46, 14881-14891, https://doi.org/10.1029/2019GL085318, 2019a.

Yue, S., Ren, L., Song, T., Li, L., Xie, Q., Li, W., Kang, M., Zhao, W., Wei, L., Ren, H., Sun, Y., Wang, Z., Ellam, R. M., Liu, C.-Q., Kawamura, K., and Fu, P.: Abundance and diurnal trends of fluorescent bioaerosols in the troposphere over Mt. Tai, China, in spring, J. Geophys. Res. Atmos., 124, 4158-4173, https://doi.org/10.1029/2018JD029486, 2019 b.

Zhang, A., Wang, Y., Zhang, Y., Weber, R. J., Song, Y., Ke, Z., and Zou, Y.: Modeling the global radiative effect of brown carbon: a potentially larger heating source in the tropical free troposphere than black carbon, Atmos. Chem. Phys., 20, 19011920, https://doi.org/10.5194/acp-20-1901-2020, 2020a.

Zhang, J., Yuan, Q., Liu, L., Wang, Y., Zhang, Y., Xu, L., Pang, Y., Zhu, Y., Niu, H., Shao, L., Yang, S., Liu, H., Pan, X., Shi, Z., Hu, M., Fu, P., and Li, W.: Trans-regional transport of haze particles from the North China Plain to Yangtze River Delta during winter, J. Geophys. Res. Atmos., 126, e2020JD033778, https://doi.org/10.1029/2020JD033778, 2021.

Zhang, Q., Shen, Z., Zhang, L., Zeng, Y., Ning, Z., Zhang, T., Lei, Y., Wang, Q., Li, G., Sun, J., Westerdahl, D., Xu, H., and Cao, J.: Investigation of Primary and Secondary Particulate Brown Carbon in Two Chinese Cities of Xi' an and Hong Kong in Wintertime, Environ. Sci. Technol., 54, 3803-3813, http://doi.org/10.1021/acs.est.9b05332, 2020b.

Zhang, Y., Forrister, H., Liu, J., Dibb, J., Anderson, B., Schwarz, J. P., Perring, A. E., Jimenez, J. L., Campuzano-Jost, P., Wang, 
https://doi.org/10.5194/acp-2021-1045

Preprint. Discussion started: 17 January 2022

(C) Author(s) 2022. CC BY 4.0 License.

(c) (1)

845 Y., Nenes, A., and Weber, R. J.: Top-of-atmosphere radiative forcing affected by brown carbon in the upper troposphere, Nat. Geos., 10, 486-489, https://doi.org/10.1038/ngeo2960, 2017.

Zhao, X. J., Zhao, P. S., Xu, J., Meng,, W., Pu, W. W., Dong, F., He, D., and Shi, Q. F.: Analysis of a winter regional haze event and its formation mechanism in the North China Plain, Atmos. Chem. Phys., 13, 5685-5696, https://doi.org/10.5194/acp-135685-2013, 2013.

850 Zhong, M. and Jang, M.: Dynamic light absorption of biomass-burning organic carbon photochemically aged under natural sunlight, Atmos. Chem. Phys., 14, 1517-1525, https://doi.org/10.5194/acp-14-1517-2014, 2014.

Zsolnay, A., Baigar, E., Jimenez, M., Steinweg, B., and Saccomandi, F.: Differentiating with fluorescence spectroscopy the sources of dissolved organic matter in soils subjected to drying, Chemosphere, 38, 45-50, https://doi.org/10.1016/S00456535(98)00166-0, 1999. 


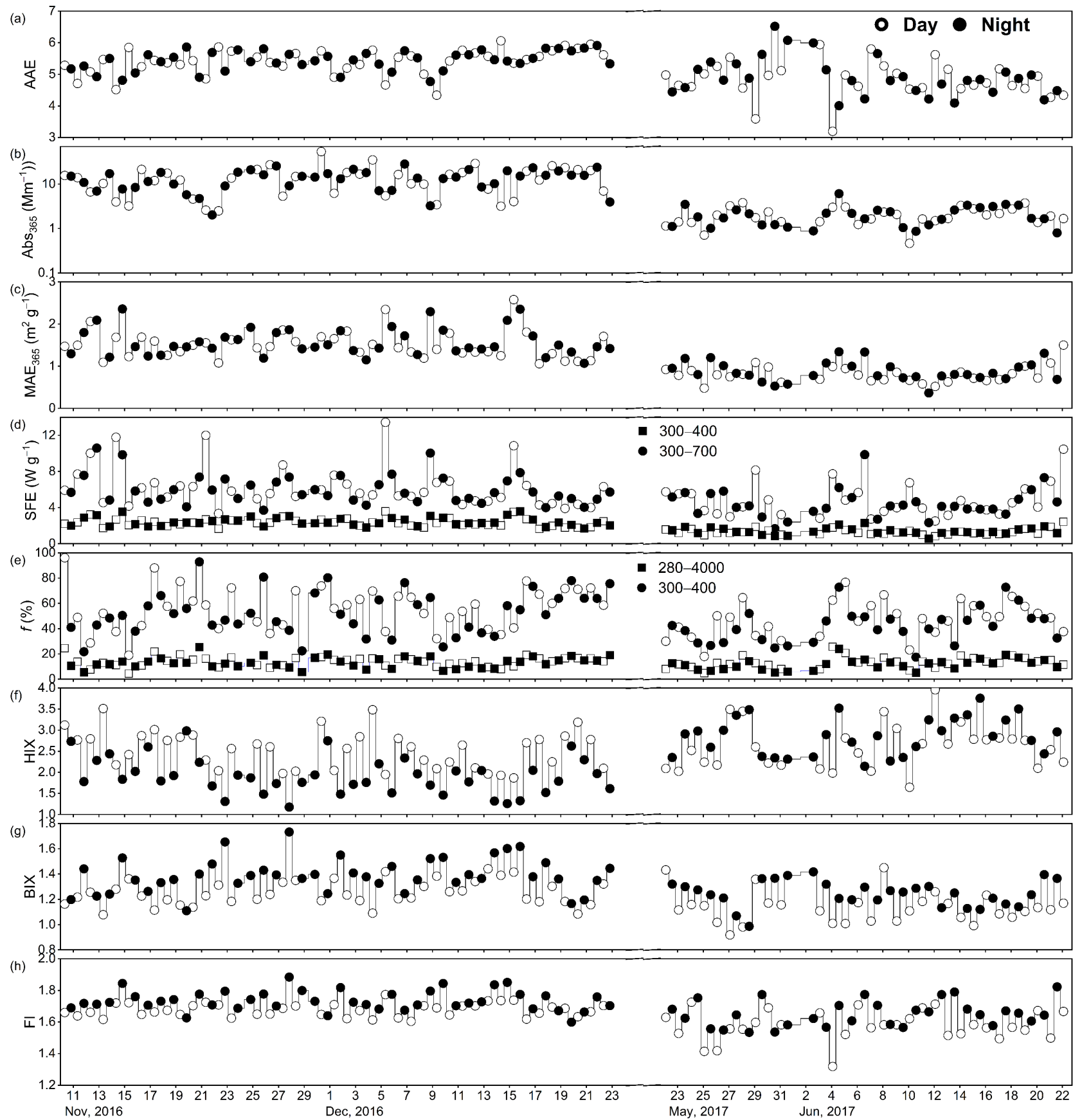

Figure 1. Temporal variations in light absorption and fluorescence properties of $\mathrm{BrC}_{\text {in }}$ Tianjin: (a) $\mathrm{AAE}_{\text {, (b) }} \mathrm{Abs}_{365}$, (c) MAE 365 , (d) SFE, (e) $f$, (f) HIX, (g) BIX, and (h) FI. 

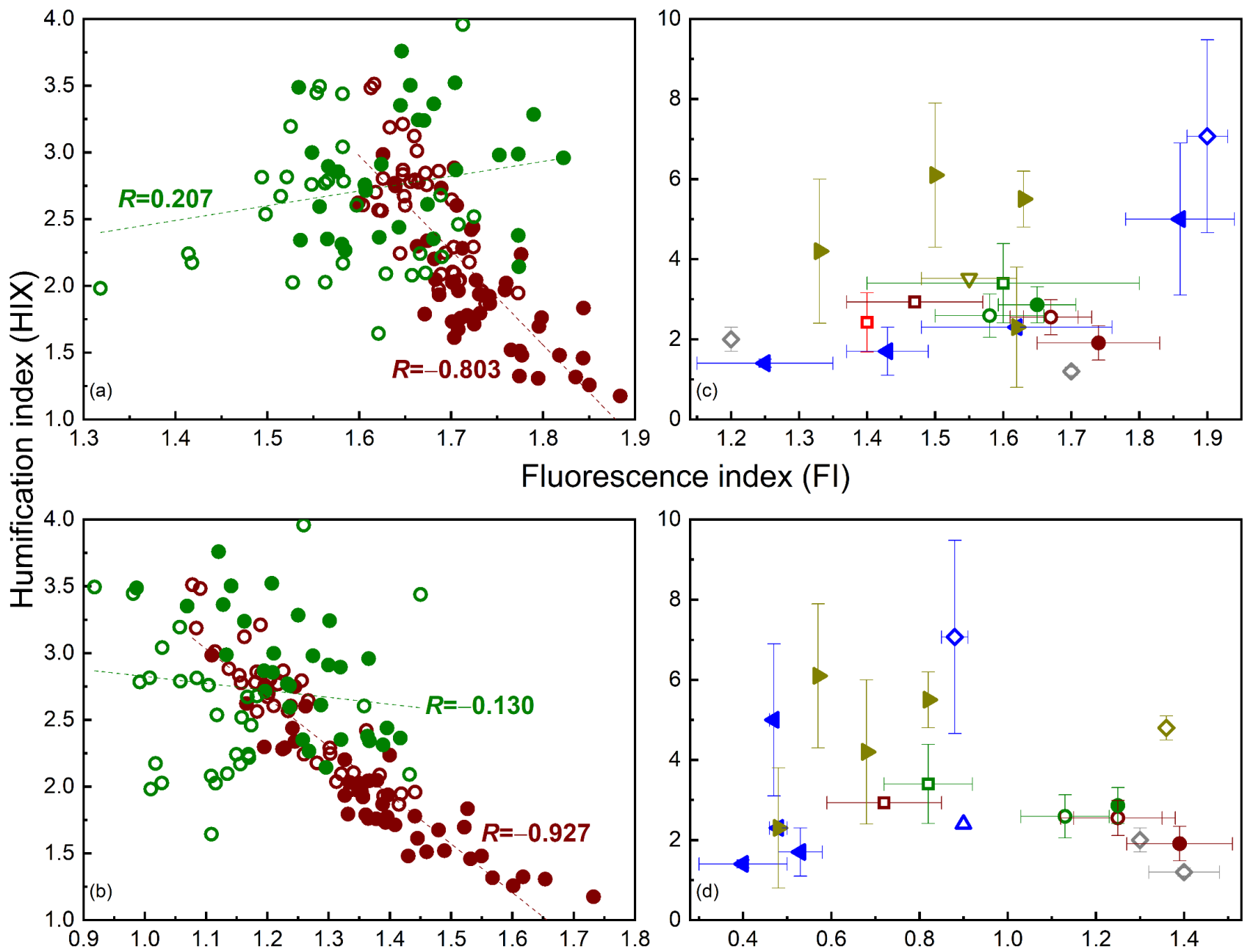

ence index (FI)

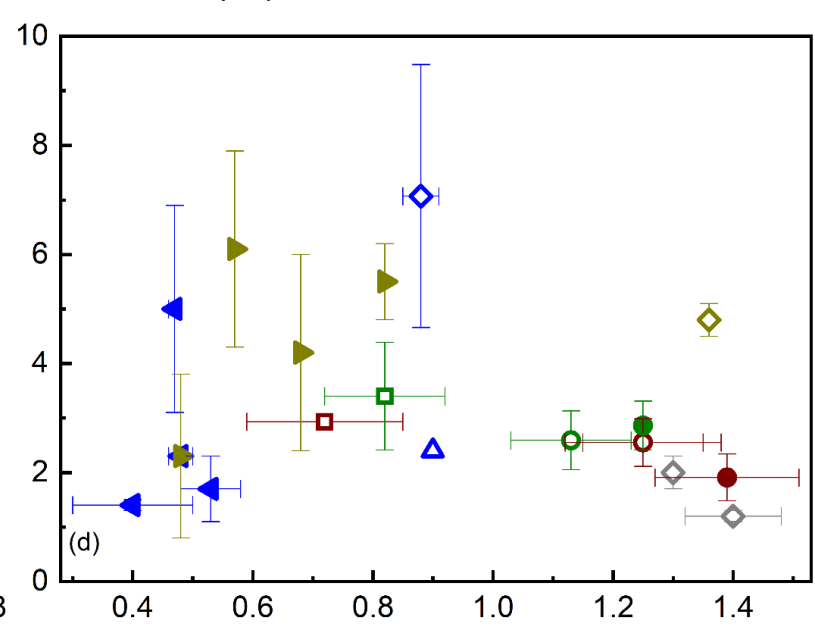

- $\mathrm{PM}_{2.5}$ (Tianjin_winter day)

\section{Biological index (BIX)}

- $\mathrm{PM}_{2.5}$ (Tianjin_summer day)

- $\mathrm{PM}_{2.5}$ (Tianjin_winter night)

- TSP(Rocky Mountains,USA) (Xie et al., 2016)

- $\mathrm{PM}_{2.5}$ (Tianjin_summer night)

- TSP(Bangkok, Thailand) (Tang et al., 2021)

- TSP(Arctic) (Fu et al., 2015)

$\diamond \mathrm{PM}_{2.5}$ (Nanjing, China) (Xie et al., 2020)

$\mathrm{M}_{2.5}$ (Lanzhou,China) (Qin et al., 2018)

$\triangle \mathrm{PM}_{2.1}$ (Mt.Tai,China) (Yue et al., 2019)

$\checkmark \mathrm{PM}_{2.5}$ (Indo-Gangetic Plain,India) (Dey et al., 2021)

Fresh SOA(Chamber) (Lee et al., 2013)

$\nabla \mathrm{PM}_{10}$ (Granada, Spain) (Mladenov et al., 2011)

Aged SOA(Chamber) (Lee et al., 2013)

Figure 2. Scatter plots of the HIX values as a function of (a) FI and (b) BIX for WSOC in Tianjin aerosols, and comparison plots of HIX with (c) FI and (d) BIX in aerosols in this study and literature. 

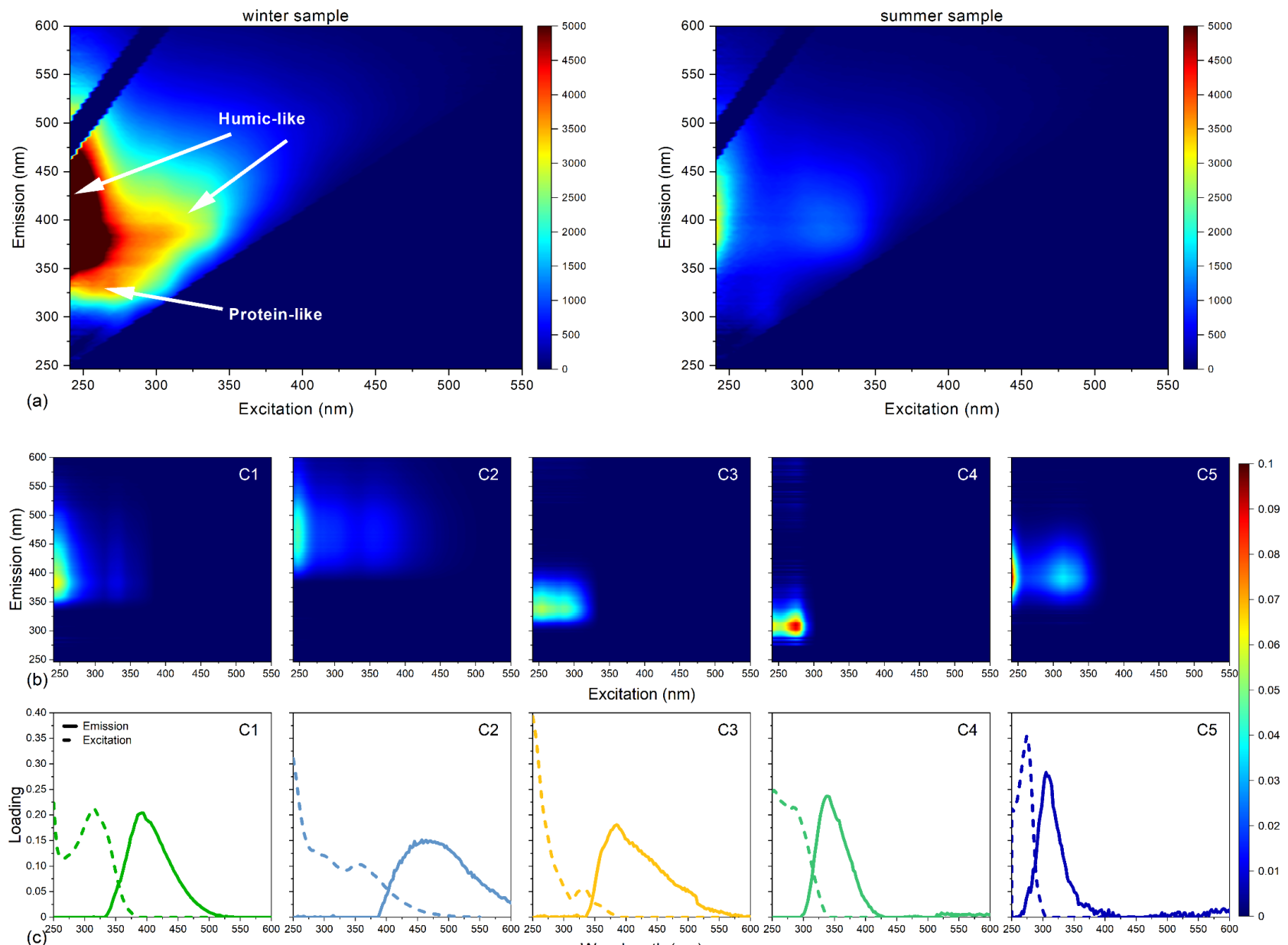
Excitation (nm)

$(c)^{250}$
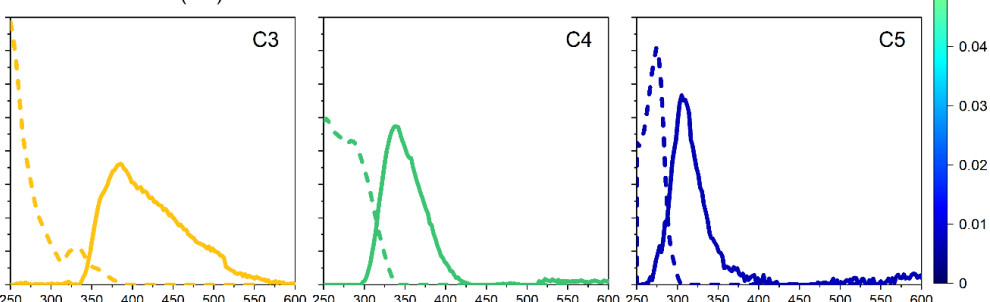

Wavelength $(\mathrm{nm})$

Figure 3. (a) Typical excitation-emission matrix (EEM) fluorescence spectra of water-soluble organic carbon in the aerosol samples collected in winter and summer, respectively. (b) Three-dimensional excitation-emission matrix of five fluorescent components (C1-C5) in BrC obtained by PARAFAC model analysis. (c) Emission and excitation spectra of each fluorescent component at peak emission and excitation wavelengths. 
https://doi.org/10.5194/acp-2021-1045

Preprint. Discussion started: 17 January 2022

(c) Author(s) 2022. CC BY 4.0 License.
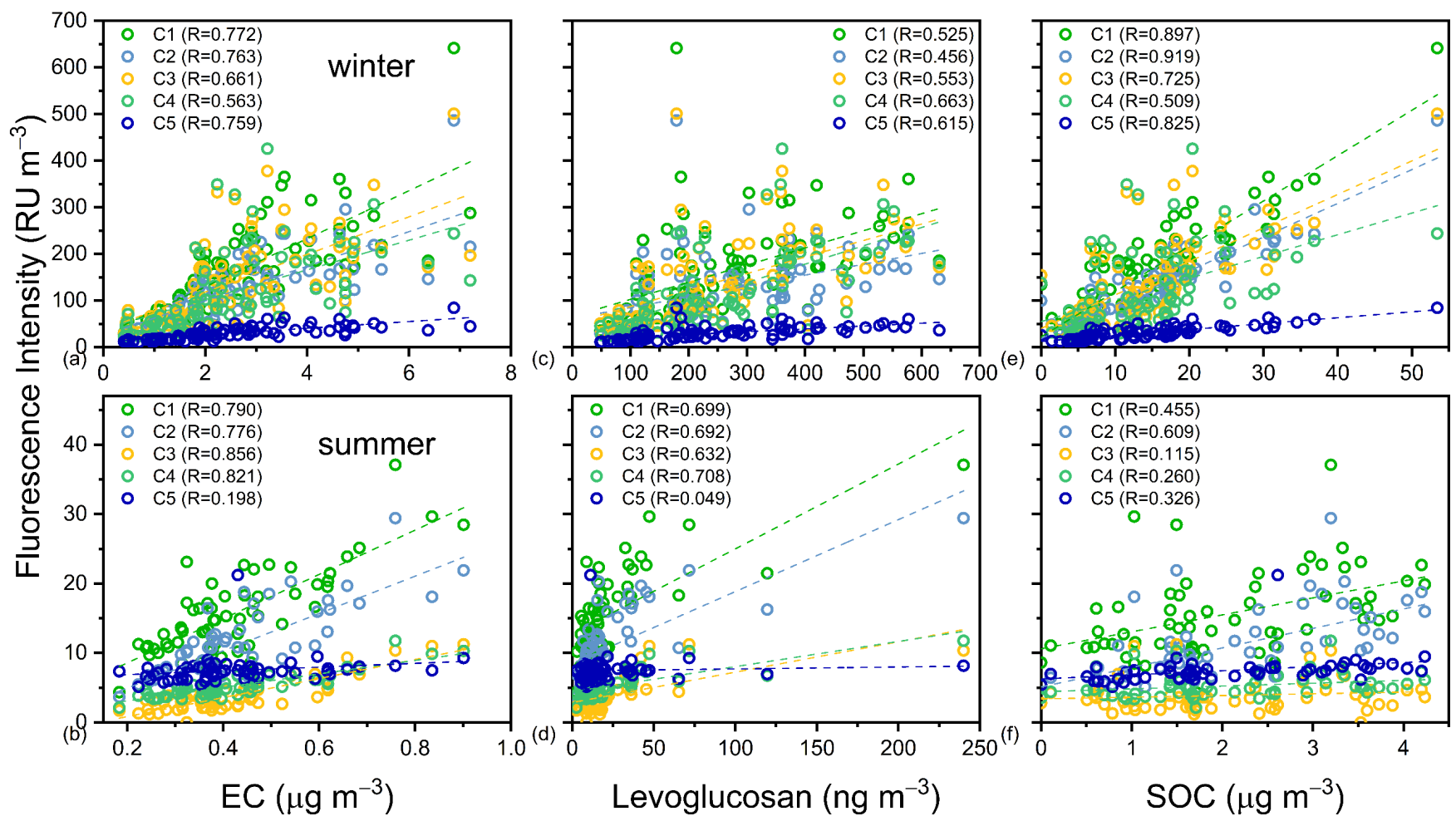

875 Figure 4. Correlations of fluorescent intensities of five fluorescent components in BrC with EC (a-b), levoglucosan (c-d), and SOC $(e-f)$ in winter and summer. 
https://doi.org/10.5194/acp-2021-1045

Preprint. Discussion started: 17 January 2022

(c) Author(s) 2022. CC BY 4.0 License.

(c) (i)
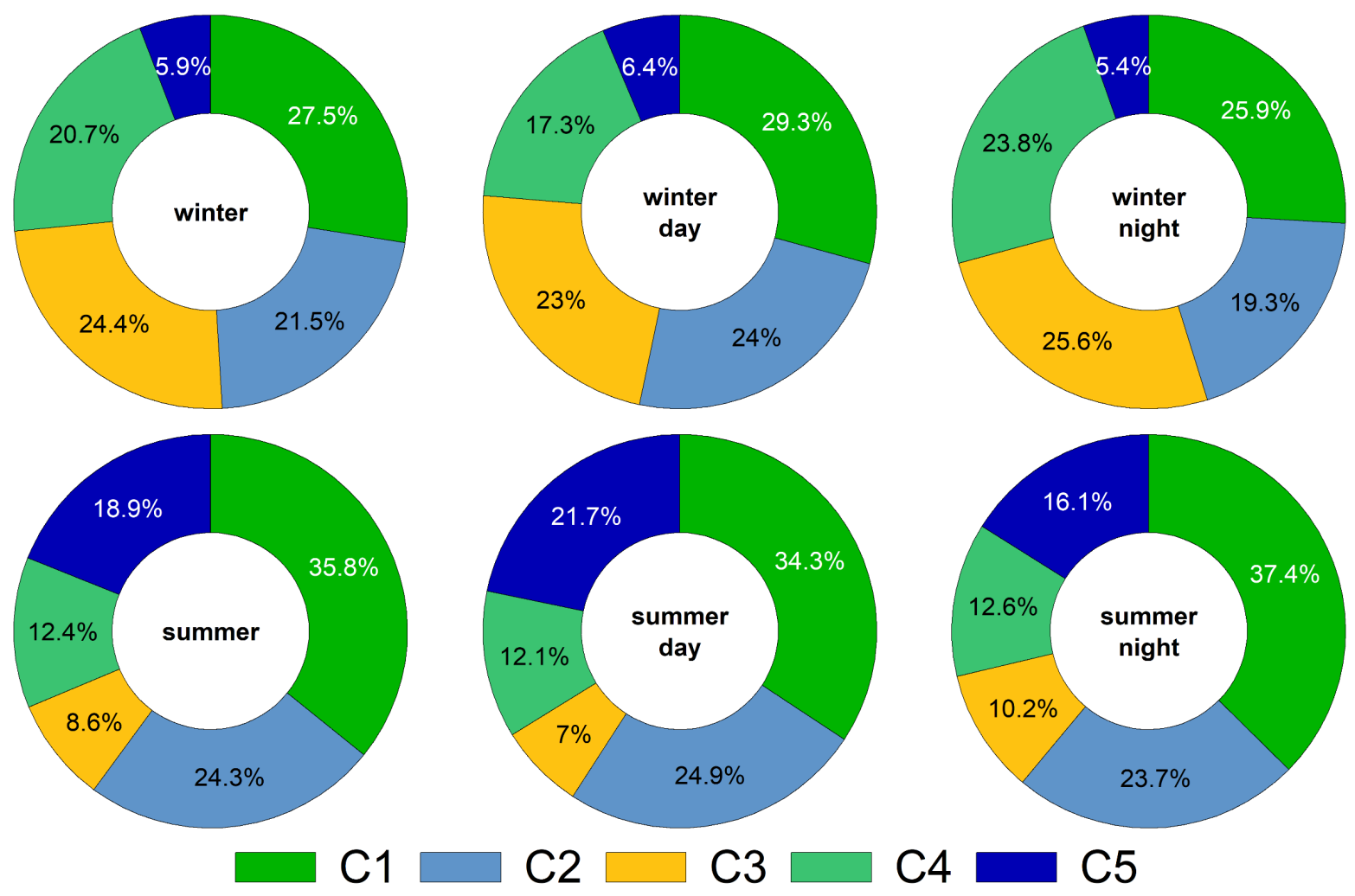

880 Figure 5. Average relative abundances of the PARAFAC-derived fluorescent components for water-soluble BrC of Tianjin aerosols in different periods. $\mathrm{C} 1, \mathrm{C} 2$ and $\mathrm{C} 3$ are humic-like components, and $\mathrm{C} 4$ and $\mathrm{C} 5$ are protein-like components. 

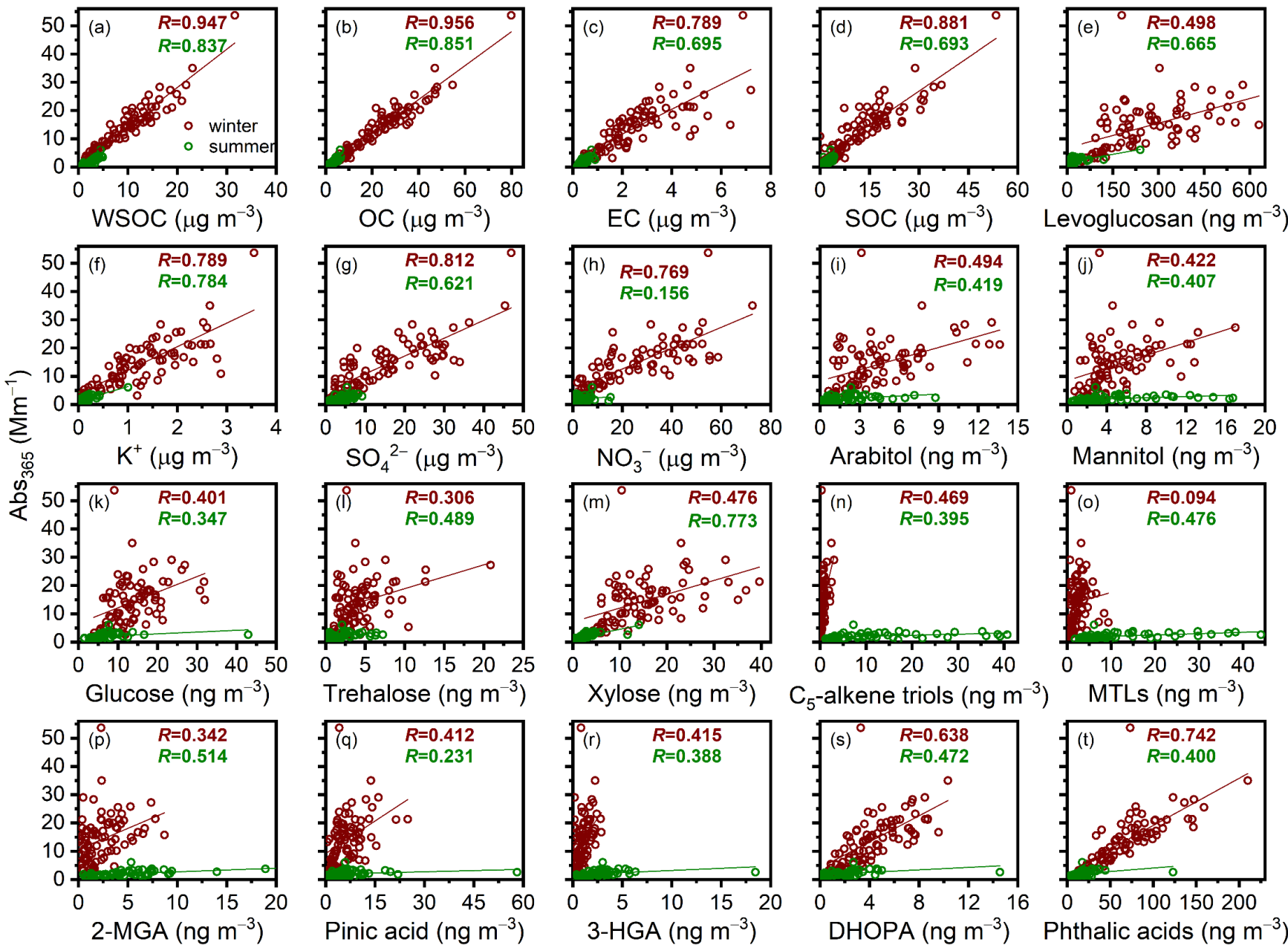

885 Figure 6. Relationships between $\mathrm{Abs}_{365}$ and chemical species of aerosols in Tianjin: (a) WSOC, (b) OC, (c) EC, (d) SOC, (e) levoglucosan, (f) $\mathrm{K}^{+}$, (g) $\mathrm{SO}_{4}{ }^{2-}$, (h) $\mathrm{NO}_{3}{ }^{-}$, (i) arabitol, (j) mannitol, (k) glucose, (l) trehalose, (m) xylose, (n) $\mathrm{C}_{5}$-alkene triols, (o) 2methyltetrols (MTLs), (p) 2-methylglyceric acid (2-MGA), (q) pinic acid, (r) 3-hydroxyglutaric acid (3-HGA), (s) 2,3-dihydroxy-4oxopentanoic acid (DHOPA), and (t) phthalic acids. 
https://doi.org/10.5194/acp-2021-1045

Preprint. Discussion started: 17 January 2022

(c) Author(s) 2022. CC BY 4.0 License.
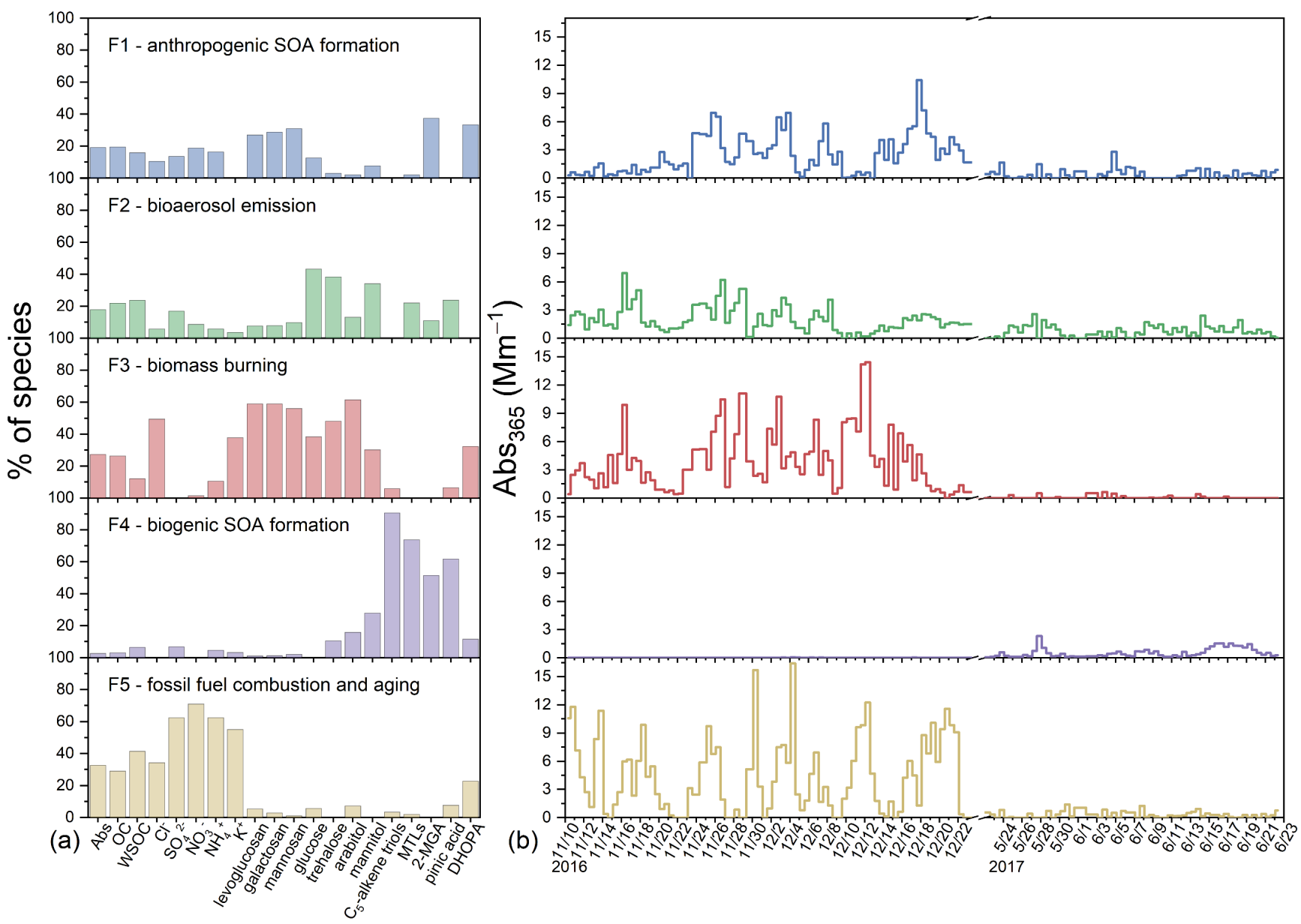

Figure 7. (a) The left figure shows the individual source profiles of the factors resolved by PMF analysis, and the right one (b) shows the temporal variations in individual factor contributions to BrC. 


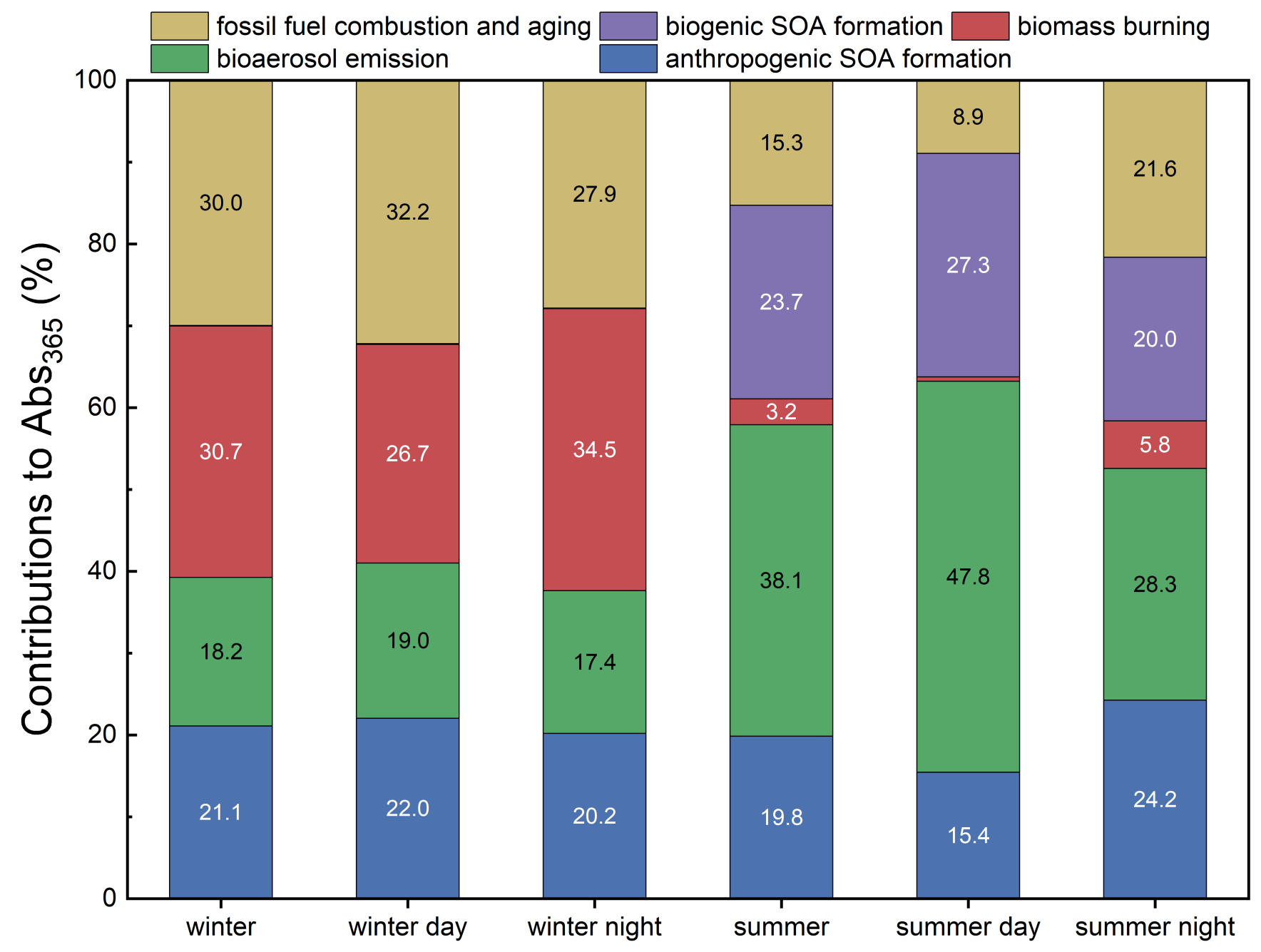

Figure 8. Relative contributions of individual sources to BrC obtained by PMF analysis with molecular marker. 
https://doi.org/10.5194/acp-2021-1045

Preprint. Discussion started: 17 January 2022

(c) Author(s) 2022. CC BY 4.0 License.

(c) (1)

Table 1. Light-absorbing and fluorescence properties of $\mathrm{BrC}$ in $\mathbf{P M}_{2.5}$ in urban Tianjin, China.

\begin{tabular}{|c|c|c|c|c|c|c|}
\hline & \multicolumn{3}{|c|}{ Summer } & \multicolumn{3}{|c|}{ Winter } \\
\hline & Day $(\mathrm{N}=30)$ & Night $(\mathrm{N}=30)$ & Average $(\mathrm{N}=60)$ & Day $(\mathrm{N}=41)$ & Night $(\mathrm{N}=43)$ & Average $(\mathrm{N}=84)$ \\
\hline \multicolumn{7}{|c|}{ Light absorption property } \\
\hline $\operatorname{Abs}_{365}\left(\mathrm{Mm}^{-1}\right)$ & $2.0 \pm 0.8$ & $2.1 \pm 1.1$ & $2.1 \pm 1.0$ & $14.4 \pm 10.3$ & $13.9 \pm 6.3$ & $14.1 \pm 8.5$ \\
\hline $\operatorname{MAE}_{365}\left(\mathrm{~m}^{2} \mathrm{~g}^{-1}\right)$ & $0.80 \pm 0.21$ & $0.88 \pm 0.24$ & $0.84 \pm 0.22$ & $1.50 \pm 0.33$ & $1.58 \pm 0.33$ & $1.54 \pm 0.33$ \\
\hline AAE & $4.8 \pm 0.6$ & $4.9 \pm 0.6$ & $4.9 \pm 0.6$ & $5.4 \pm 0.4$ & $5.4 \pm 0.3$ & $5.4 \pm 0.4$ \\
\hline $\mathrm{E}_{250} / \mathrm{E}_{365}$ & $5.7 \pm 0.7$ & $5.6 \pm 0.7$ & $5.7 \pm 0.7$ & $5.7 \pm 0.6$ & $5.6 \pm 0.6$ & $5.6 \pm 0.6$ \\
\hline$k_{365}$ & $0.040 \pm 0.010$ & $0.043 \pm 0.012$ & $0.042 \pm 0.011$ & $0.074 \pm 0.016$ & $0.078 \pm 0.016$ & $0.076 \pm 0.016$ \\
\hline$f_{300-400}(\%)$ & $47.5 \pm 13.9$ & $41.7 \pm 13.6$ & $44.6 \pm 13.9$ & $56.2 \pm 16.8$ & $52.6 \pm 17.0$ & $54.3 \pm 16.9$ \\
\hline$f_{280-4000}(\%)$ & $13.4 \pm 4.5$ & $11.7 \pm 4.4$ & $12.5 \pm 4.5$ & $14.0 \pm 4.0$ & $13.1 \pm 4.3$ & $13.5 \pm 4.1$ \\
\hline $\mathrm{SFE}_{300-700}\left(\mathrm{~W} \mathrm{~g}^{-1}\right)$ & $4.8 \pm 1.8$ & $4.4 \pm 1.6$ & $4.6 \pm 1.7$ & $6.3 \pm 2.3$ & $6.0 \pm 1.6$ & $6.2 \pm 2.0$ \\
\hline $\mathrm{SFE}_{300-400}\left(\mathrm{~W} \mathrm{~g}^{-1}\right)$ & $1.3 \pm 0.4$ & $1.4 \pm 0.4$ & $1.4 \pm 0.4$ & $2.3 \pm 0.5$ & $2.4 \pm 0.5$ & $2.4 \pm 0.5$ \\
\hline \multicolumn{7}{|c|}{ Fluorescence property } \\
\hline FI & $1.58 \pm 0.09$ & $1.65 \pm 0.08$ & $1.61 \pm 0.10$ & $1.67 \pm 0.04$ & $1.74 \pm 0.06$ & $1.71 \pm 0.06$ \\
\hline BIX & $1.13 \pm 0.12$ & $1.25 \pm 0.10$ & $1.19 \pm 0.13$ & $1.25 \pm 0.10$ & $1.39 \pm 0.13$ & $1.32 \pm 0.14$ \\
\hline HIX & $2.59 \pm 0.54$ & $2.86 \pm 0.45$ & $2.73 \pm 0.51$ & $2.55 \pm 0.44$ & $1.91 \pm 0.43$ & $2.22 \pm 0.54$ \\
\hline
\end{tabular}

